Dept. of Anatomy,

Faculty of Medicine, Assiut University, Assiut, Egypt

\title{
QUANTITATIVE MORPHOMETRIC STUDY ON CYCLOPHOSPHAMIDE TESTICULAR TOXICITY IN ADULT ALBINO RATS
}

(With 12 Tables and 13 Figures)

\author{
By \\ WAFAA MUBARAK, A. EDWARD; HODA AHMED \\ and S. ANWAR
}

(Received at 12/3/2009)

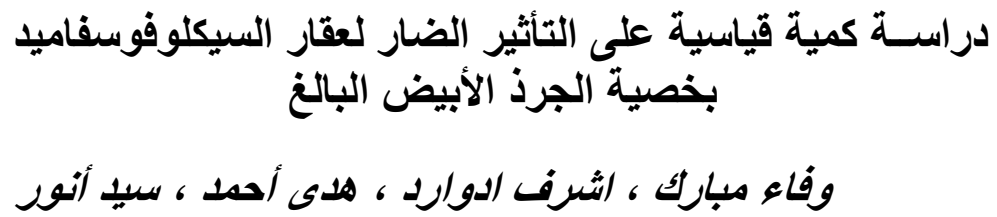

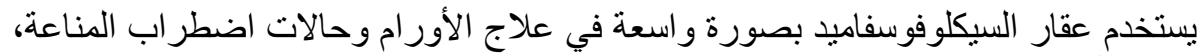

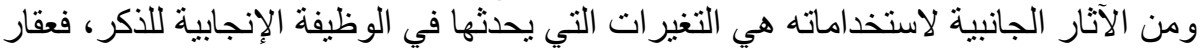

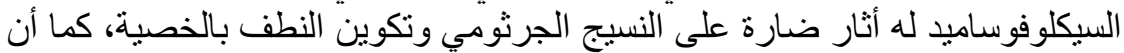

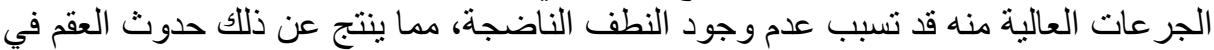

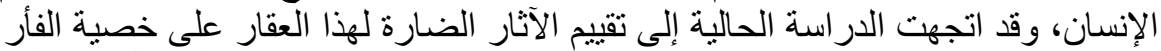

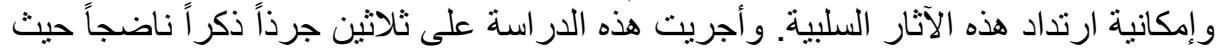

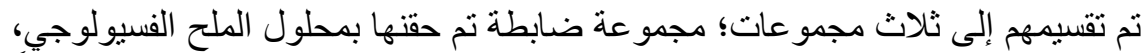

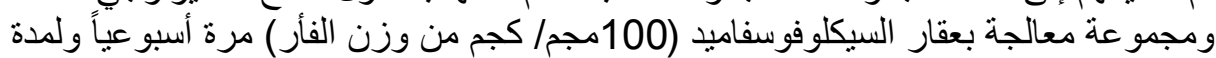

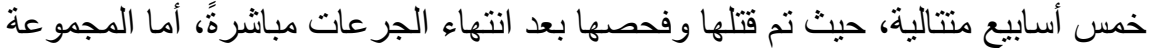

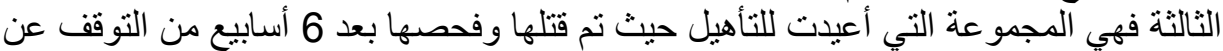
إعطاء العقار . وقد تم إعداد قطاعات شبه رقيقة من المجمو عات الثلاثثة و أجريت عليت عليها

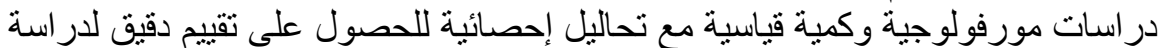

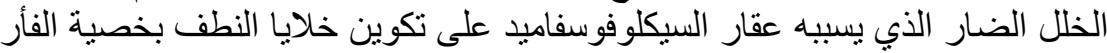

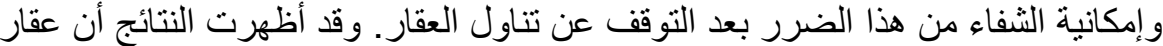

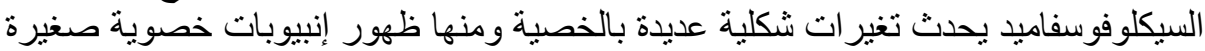

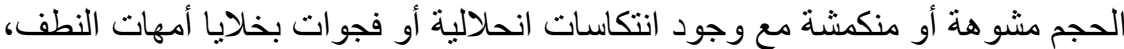

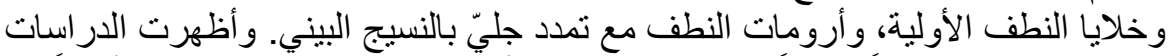

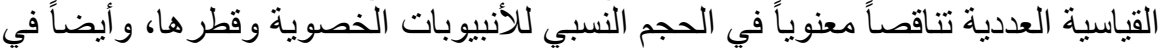

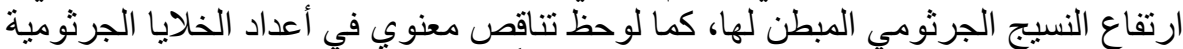

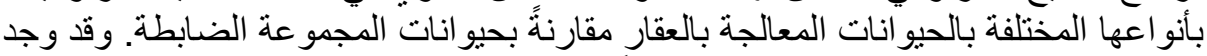

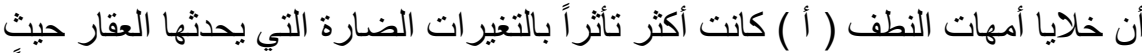
أظهرت تغيَّر ات انحلالية و اضحة في التركيب مع وجود تناقص معنوي في العدد مقارنةً 
بالمجموعة الضابطة. وبالنسبة لخلايا النطف الأولية وكذا أرومات النطف فقد أبديا أيضاً

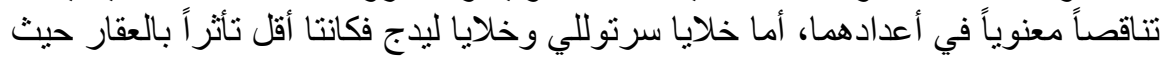

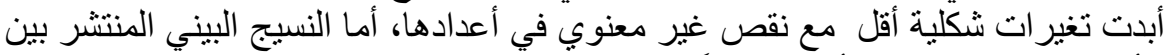

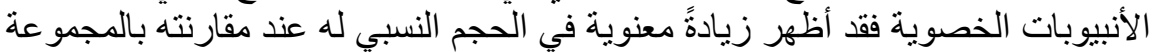

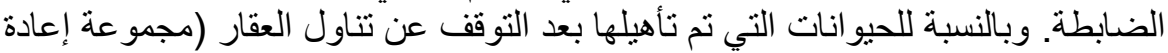

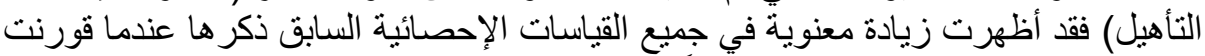

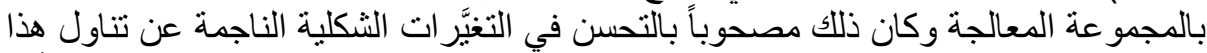

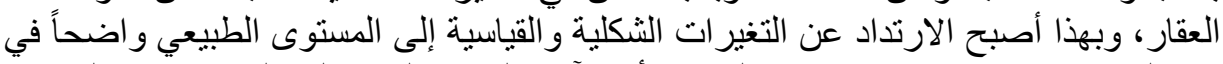

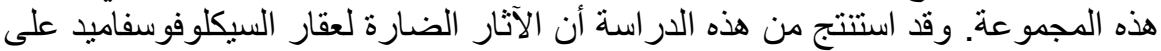

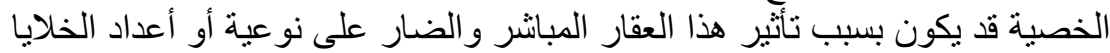

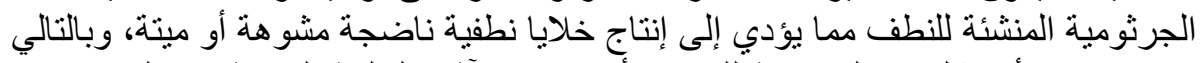

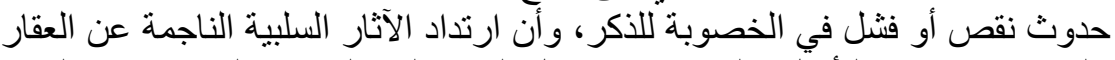

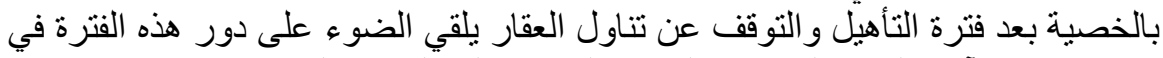

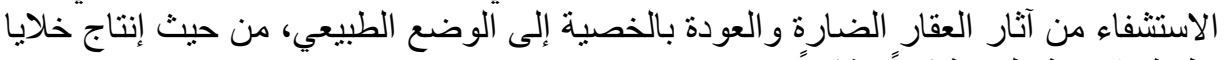
نطفية ناضجة طبيعية كماً وشكلاً.

\section{SUMMARY}

A side effect of cyclophosphamide (CP), an alkylating agent widely used to treat tumors and autoimmune disorders is the alteration of male reproductive function. $\mathrm{CP}$ is extremely dangerous to the germinal epithelium and damage to spermatogenesis. High doses can cause azoospermia which can result infertility in humans. This study is focused on the evaluation of toxicological effect of cyclophosphamide on male rat testis and the possible reversibility of these toxic effects. Thirty adult male rats were divided into three groups: vehicle-treated (control), CPtreated and rehabilitated groups. CP was administrated intraperitoneally $(100 \mathrm{mg} / \mathrm{kg} /$ week) for five successive weeks, and semithin sections from testicular tissue were prepared and examined after last injection (treated group) and six weeks later (rehabilitated group). A quantitative morphometric study and statistical analysis were applied for accurate and efficient assessment of spermatogenic impairment induced by CP. The CP treated group showed various morphological alterations in the testis such as reduction in the size and distortion in the shape of the seminiferous tubules with degeneration and vacuolation in spermatogonia, spermatocytes and spermatids associated with marked interstitial oedema. In addition, the CP induced significant decreases in volume proportion, diameter and epithelial height of the seminiferous tubules together with a significant reduction in the number of different germ cells in the treated animals. Interestingly, spermatogonia A 
appeared to be target cells for the damaging effect of $\mathrm{CP}$ in the testis that presented severe degenerative changes in structure along with significant reduction in number in the treated group animals. Furthermore, the number of primary spermatocytes and round spermatids decreased significantly in CP- treated group. The Sertoli and Leydig cells, however, appeared to be less affected to $\mathrm{CP}$ toxicity; exhibiting insignificant decrease in number as well as less morphological alterations. The Interstitial spaces of treated group animals showed a highly significant increase in its volume proportion, when compared to the control animals. Meanwhile, the rehabilitated group showed significant increases for aforementioned variables in comparison to the CP- treated group, associated with reversal of morphological changes towards normalcy. Based on the results from the present study it is concluded that the morphological alterations induced by $\mathrm{CP}$ toxicity were further substantiated by morphometric findings in the testicular tissue of rat. A direct toxicity of $\mathrm{CP}$ to the number and quality of spermatogenic compartment may be considered as one of the mechanisms of action of CP in producing the abnormal and dead sperms that alter fertility. By the reversal of morphological and stereological changes towards normalcy, the role of rehabilitation is illuminated in $\mathrm{CP}$ induced testicular damage.

Key words: Testicular toxicity, Cyclophosphamide, Morphometry, Spermatogenic cells

\section{INTRODUCTION}

Cyclophosphamide (CP) is in the nitrogen mustard group of alkylating chemotherapeutic agents. It is one of the most frequently used antitumor agents for the treatment of a broad spectrum of human cancers, including leukemia, lymphoma, germ cell tumors and carcinomas of breast, lung, and cervix (Friedman et al., 1999). It is also used as an immunosuppressive agent in the treatment of arthritis, nephrotic syndrome, multiple sclerosis and other nonmalignant diseases, as well as for organ transplantation (Perini et al., 2007; Uber et al., 2007). The therapeutic activity of CP is the result of chemically reactive metabolites, phosphoramide mustard, that alkylate DNA and protein, producing cross-links, and inability to synthesize DNA, and ultimately kill cancer cells (Dollary, 1999; wang, et al., 2007). The cytotoxic effect of cyclophosphamide targets rapidly dividing cells, as well as the cancerous cells, makes the highly proliferative testis, especially, a good 
target for damaging effects in humans and experimental animals (Fraiser et al., 1991; Ahmad et al., 2008).

The CP is extremely dangerous to the germinal ephitelium and causes damage and impairment to spermatogenesis in the testis (Clopi et al., 2004; Selvakumar et al., 2006a; Elangovan et al., 2006). It causes a certain degree of oligozoospermia to azoospermia associated with increased levels of follicular stimulating hormone (FSH) (Ridola et al., 2009 )which can result in human infertility (Tripathi and Jena, 2008). Further, it has been reported that chronic low dose administration of $\mathrm{CP}$ can decrease the weight of reproductive organs (Das et al., 2002), impair male fertility (Trasler et al., 1986), increase the post implantation loss and fetal malformation and can also alter growth and development of the next generation in rats (Higuchi et al., 1995).

Animal studies have revealed that treatment of rats/mice with $\mathrm{CP}$ led to decreased DNA synthesis in spermatogonia and protein synthesis in spermatids as well as biochemical and histological alterations in the testis and epididymis (Meistrich et al., 1995; Kaur et al., 1997). CP induces morphological alterations such as reduction in size of the seminiferous tubules, number of the seminiferous tubules, degeneration and vacuolation spermatogonia, spermatocytes and spermatids in dose dependent manner (Tripathi, Jena, 2008). It has already been reported that CP treatment causes impairment of sperm in mice, lowered the sperm parameters in rats and induces abnormality in sperm head morphology (Elangovan et al., 2006; Codrington et al., 2007).

It was found that $\mathrm{CP}$ treatment resulted in a decreased number of early germ cells and reduced spermatogenesis (Schrader et al., 2001\&Tripathi and Jena, 2008). The morphometric study of different stages in spermatogenic cycle indicates that testicular toxicity can be detected from day seven, even after a single oral administration of $\mathrm{CP}$ at the dose $100 \mathrm{mg} / \mathrm{kg}$ in rat (Matsui et al., 1995). Spermatogonia are the target cell type affected at time of CP injection (Russell and Russell 1991 \& Elangovan et al., 2006) and a decrease in the number of spermatogonia can be detected at day 3 after $\mathrm{CP}$ exposure (Matsumoto et al., 2000). The death of stem spermatogonia is most likely attributed to the mechanism of azoospermia (Meistrich, 1986). A complete loss of germinal cells and spermatocytes were suggested at the highest dose of $200 \mathrm{mg} / \mathrm{kg}$ of CP (Tripathi and Jena, 2008).

The precise mechanism by which $\mathrm{CP}$ causes testicular toxicity is unknown; however, It has already been reported that $\mathrm{CP}$ induced apoptosis in a stage specific manner in spermatogonia and spermatocyte 
of rat testes (Cai et al., 1997). CP has been shown to inhibit proliferation of germ cells due to its DNA and chromosome damaging effect during spermatogenesis (Andreson et al., 1995; Schimenti et al., 1997). Further, $\mathrm{CP}$ has been shown to alter the expression of stress response genes, most dramatically in round spermatids (Aguilar-Mahecha et al., 2002; Chamorro- Cevallos et al., 2008) and to have varying effects on spermatogenesis-related genes in the rat testes (Fukushima et al., 2005). It has been postulated that the cyclophosphamide-induced changes in gene expression during spermatogenesis were a reflection of damaged chromatin (Hales et al., 2005). Recently, CP alters the sperm chromatin structure as well as the composition of sperm head basic proteins in male rats (Codrington et al., 2007).

There was tendency of recovery in the spermatogenesis observed over time, at lower doses of CP- treated groups as compared to higher doses (Meistrich et al., 1992; Elangovan et al., 2006). Recovery of spermatogenesis has to begin at the beginning after drug induced azoospermia and continues until the germ cells repopulate the testes adequately for the spermatogenic process of differentiation and maturation (Ahmad et al., 2008). The presence of spermatogonia stem cells is a prerequisite for being able to stimulate recovery. Spermatogenesis fails to recover not because stem spermatogonia are killed, but rather because surviving stem spermatogonia fail to differentiate (Kangasniemi et al., 1996). Hormonal manipulation using GnRH (gonadotrophin releasing hormones) agonists or systemic testosterone has been shown to have a cytoprotective effect on spermatogenic cells during treatment with chemotherapy in rats (Meistrich et al., 2000). Astaxanthin (AST) treatment in mice (Tripathi and Jena, 2008), Yukmijihwang-tang (YJT) in rat (Oh et al., 2007) or Spirulina (SP) treatment (Chamorro-Cevallos et al., 2008) can also protect against adverse reproductive effects of $\mathrm{CP}$ thereby, enhancing spermatogenesis.

\section{MATERIALS and METHODS}

\section{I- Experimental animals}

Thirty adult male albino rats, three months old, were used in this study. They were obtained from the animal house of Assiut University and maintained in the animal house under normal conditions, with free access to food and water in the normal daily light and darkness cycle.

\section{II-Drug preparation:}


Vials containing $200 \mathrm{mg}$ of the pure powder form of cyclophosphamide (CP) dissolved in $10 \mathrm{ml}$ dextrose 5\%were used, so each one $\mathrm{ml}$ of the resulting solution contained $20 \mathrm{mg}$ of the drug.

\section{III-Experimental protocol:}

The experimental animals were divided into 2 groups:

Group A: Control group (10 animals); rats were injected intraperitoneally (I.P.) with dextrose $5 \%$.

Group B: Experimental group (20 animals); rats were treated by I.P. injection of CP in a dose equal to $100 \mathrm{mg} / \mathrm{kg}$ body weight once weekly for 5 successive weeks (Velez et al., 1989). At the end of the treatment period the treated animals were subdivided into 2 subgroups; (a) and (b), 10 animals each.

Animals of subgroup (A) were sacrificed after last injection to investigate the toxic effect of $\mathrm{CP}$ administration on the testis, while animals of subgroup $(B)$ Left for another 6 weeks without any treatment and then sacrificed to investigate the rehabilitation effect on the testis.

\section{Tissue preparation for histological processing:}

The animals were first anaesthetized by ether and intracardially perfused with $10 \mathrm{ml}$ of heparnized isotonic solution in a concentration of 130 IU/10 gm body weight (Ye et al., 1993), to facilitate testicular perfusion via the cardiac route. This was followed by intracardiac fixation with $2.5 \%$ cacodylate buffered gluteraldehyde. The wall of the scrotum was dissected and the testis was extracted.

\section{Weight and volume of the testis:}

The weights of the testes were measured using a satorial balance. The volumes of the testes were determined by means of water displacement technique (El-Shennawy 1991).

\section{Histological technique for semithin sections:}

The excised testes were homogenized in $5 \%$ gluteraldehyde in $0.1 \mathrm{M}$ sodium cacodylate buffer at $4 \mathrm{oC}$ for $2-48$ hours and were set for histological processing. The testes were sliced and the testicular samples were routinely trimmed, post-fixed in $1 \%$ osmium tetraoxide, dehydrated and then embedded in epon for preparation of semithin sectioning. The semithin sections (1.0 micron) were stained by $2 \%$ aqueous toluidine blue and examined under a light microscope.

\section{Stereological methods:}

Histological quantification was performed by image analysis system (Leica Q500). The following parameters were determined for the tested groups of animals:

1. Volume proportion of the seminiferous tubules and interstitial spaces. 
2. The diameter of the seminiferous tubules.

3. The epithelial height of the seminiferous tubules.

4. The cell number per cross section of a seminiferous tubule for Sertoli cells, spermatogonia, primary spermatocytes and round spermatids.

5. Number of Leydig cells per high power field.

\section{Statistical Analysis}

All the quantitative data from this study were analyzed statistically. The results were expressed as the mean \pm standard deviation (SD). Differences between groups were assessed by one way analysis of variance (ANOVA) according to Peterson (1985). Post hoc testing was performed for inter-group comparisons using the least significance difference (LSD) test. A P-value $<0.05$ was considered significant. Statistical significance at P-values <0.001, <0.05 have been given respective symbols in the tables.

\section{RESULTS}

\section{Histological Findings}

The normal testicular tissue in control group appeared to be formed of regular rounded or oval seminiferous tubules and interstitial tissue in-between. Each tubule was surrounded by regular basement membrane and lined by organized germinal epithelium and Sertoli cells, which radially arranged in-between (Fig. 1A). The CP treated testis revealed atrophic shrunken seminiferous tubules with markedly distorted shape and thickened irregular basement membrane with impaired spermatogenesis and multiple degenerating vacuoles, mostly towards the basement membrane (Fig. 1B). The germinal epithelium showed marked dispersion, disorganization and loss integrity of its cellular components. The germinal cell populations exhibited signs of degeneration and vaculations in their cytoplasm and nuclei, meanwhile other germ cells were completely destroyed and replaced by degenerative vacuoles (Fig. 1B). Spermatogonia cells appeared to be more affected by CP toxicity, as most of them disappeared and replaced by degenerative vacuoles near the basement membrane. Both primary spermatocytes and round spermatids showed degenerative changes as well, however, the Sertoli and Leydig cells were apparently less affected (Fig. 1B). The interstitial spaces showed a clear increase in amount and presented dilated blood vessles with marked interstitial oedema. Some seminiferous tubules contained degenerated tissues and debris in their lumen or showed absence of mature sperms. The rehabilitated testis showed an improved picture which was further substantiated by the normal histologic findings of seminiferous tubules resident with mature 
sperms, restoration of normal organized spermatogenesis along with less degenerative changes in germ cells and normal interstitial tissue both in amount and components. Other tubules were still showed degenerative vacuoles (Fig. 1C).

\section{Stereological Findings}

\section{Testicular weight:}

The present study revealed that the mean testicular weight for the control, treated and rehabilitated groups was $1.70 \pm 0.06 \mathrm{gm}, 1.59 \pm 0.05$ gm and $1.68 \pm 0.06 \mathrm{gm}$, respectively. Analysis of variance showed that the difference in the testicular weight between the three tested groups was insignificant $(\mathrm{P}<0.24)$ (Table 1a). The post Hoc tests revealed nonsignificant differences between control and treated or between treated and rehabilitated groups (Table 1b).

\section{Testicular volume:}

The present study revealed that the mean testicular volume of the control, treated and rehabilitated groups was $1.47 \pm 0.02 \mathrm{ml}, 0.97 \pm 0.03$ $\mathrm{ml}$ and $1.35 \pm 0.02 \mathrm{ml}$, respectively. Analysis of variance revealed highly significant difference in the testicular volume between the three tested groups $(\mathrm{P}<0.001)$ (Table $2 \mathrm{a})$. The post Hoc tests revealed significant differences between control and treated and between treated and rehabilitated groups $(\mathrm{P}<0.05)$ (Table $2 b)$.

\section{Diameter of seminiferous tubules:}

Analysis of variance test for diameter of seminiferous tubules indicates a significant difference between the diameters of seminiferous tubules of control, treated and rehabilitated groups ( $p<0.05)$. The mean diameter of seminiferous tubules of control, treated and rehabilitated groups was $297.9 \mu \mathrm{m}, 260.3 \mu \mathrm{m}$ and $290.5 \mu \mathrm{m}$ respectively (Table $3 \mathrm{a}$ ). The post Hoc tests revealed significant differences between control and treated and between treated and rehabilitated groups $(\mathrm{P}<0.05)$ (Table $3 b)$.

\section{Volume proportion of seminiferous tubules:}

Analysis of variance for the volume proportion of the seminiferous tubules indicates highly significant difference in the volume proportion of the seminiferous tubules between the three tested groups $(\mathrm{p}<0.001)$. The mean volume proportion of seminiferous tubules of control, treated and rehabilitated group was $90.1633 \%, 59.5800 \%$ and $88.0867 \%$ respectively (Table $4 \mathrm{a}$ ). The post Hoc tests revealed highly significant differences between control and treated, also between treated and rehabilitated groups ( $\mathrm{P}<0.001$ ) (Table 4b).

\section{Epithelial height within the seminiferous tubules:}


Analysis of variance of the epithelial height within the seminiferous tubules indicates a significant difference between control, treated and rehabilitated groups $(\mathrm{P}<0.05)$. The mean epithelial height within the seminiferous tubules of control, treated and rehabilitated groups was $90.8 \mu \mathrm{m}, 74.1 \mu \mathrm{m}$ and $75.1 \mu \mathrm{m}$ respectively (Table 5a). The post Hoc tests revealed significant differences between control and treated, also between treated and rehabilitated groups $(\mathrm{P}<0.05)$ (Table 5b).

\section{Number of Sertoli cells per cross section of a seminiferous tubule:}

The present study revealed that the mean number of sertoli cells per cross section of a seminiferous tubule in control, treated and rehabilitated groups was $16 \pm 1.76,14.8 \pm 1.92$ and $15.2 \pm 0.3$ respectively. Analysis of variance for Sertoli cell number per cross section of a seminiferous tubule reveals insignificant difference between the three tested groups $(\mathrm{P}<0.63)$ (Table 6a). The post Hoc tests revealed insignificant differences between control and treated, also between treated and rehabilitated groups (Table $6 b$ ).

7. Number of type A spermatogonia per cross section of a seminiferous tubule:

The mean number of type A- spermatogonia per cross section of a seminiferous tubule of the control, treated and rehabilitated groups was $18.49 \pm 2.4,7.19 \pm 0.79$ and $14.69 \pm 1.75$ respectively in this study. Analysis of variance for the number of type A-spermatogonia per cross section of a seminiferous tubule revealed a highly significant difference between the three tested groups $(\mathrm{P}<0.001)$ (Table $7 \mathrm{a})$. The post Hoc tests revealed significant differences between control and treated, also between treated and rehabilitated groups $(\mathrm{P}<0.05)$ (Table $7 \mathrm{~b})$.

8. Number of type B-spermatogonia per cross section of a seminiferous tubule:

The present study revealed that the mean number of type Bspermatogonia per cross section of a seminiferous tubule in control, treated and rehabilitated groups was $21 \pm 59,14.7 \pm 0.26$ and $17.8 \pm 2.1$ respectively. Analysis of variance for the number of type Bspermatogonia per cross section of a seminiferous tubule revealed significant difference among the three tested groups $(\mathrm{P}<0.05)$ (Table 8a). The post Hoc tests revealed significant differences between control and treated, also between treated and rehabilitated groups $(\mathrm{P}<0.05)$ (Table 8b).

9. Number of pachytene primary spermatocytes per cross section of 


\section{a seminiferous tubule:}

The mean number of pachytene primary spermatocytes per cross section of a seminiferous tubule of control, treated and rehabilitated groups was $50.8 \pm 2.5,36.1 \pm 0.36$ and $46 \pm 2.76$ respectively as revealed in the present study. Analysis of variance for this number showed a highly significant difference between the three tested groups $(\mathrm{P}<0.001)$ (Table 9a). The post Hoc tests revealed significant differences between control and treated, also between treated and rehabilitated groups $(\mathrm{P}<0.05)$ (Table $9 \mathrm{~b})$.

\section{Number of round spermatids per cross section of a seminiferous tubule:}

The present study revealed that the mean number of round spermatids per cross section of a seminiferous tubule in the control, treated and rehabilitated groups was $155.5 \pm 18.6,115.2 \pm 5.7$ and 136.6 \pm 20.6 respectively. Analysis of variance for the number of round spermatids per cross section of a seminiferous tubule revealed a significant difference between the three tested groups $(\mathrm{P}<0.05)$

(Table 10a). The post Hoc tests revealed significant differences between control and treated, also between treated and rehabilitated groups $(\mathrm{P}<0.05)$ (Table 10b).

\section{Volume proportion of interstitial spaces:}

The present results revealed that the mean volume proportion of interstitial spaces for the control, treated and rehabilitated groups was $9.8267 \%, 40.4100 \%$ and $11.9033 \%$ respectively. Analysis of variance for the volume proportion of interstitial spaces of all studied animals revealed highly significant difference between the three tested groups $(\mathrm{P}<0.001)$ (Table 11a). The post Hoc tests revealed highly significant differences between control and treated, also between treated and rehabilitated groups $(\mathrm{P}<0.001)$ (Table $11 \mathrm{~b})$.

\section{Leydig cell number per high power field (Magnification 1000):}

The present study revealed that the mean Leydig cell number per high power field for the control, treated and rehabilitated groups was $11.75 \pm 1.5,10 \pm 0.8$ and $10.75 \pm 1.2$ respectively. Analysis of variance for the Leydig cell number per high power field of all studied animals revealed insignificant difference between the three tested groups $(\mathrm{P}<0.18)$ (Table 12a). Also, the post Hoc tests revealed insignificant differences between control and treated as well as between treated and rehabilitated groups (Table 12b).

Table (1a): Shows means of testicular weights (gm) and their statistical 
analysis for control, cyclophosphamide treated and rehabilitated groups.

\begin{tabular}{|l|c|c|c|c|}
\hline \multicolumn{1}{|c|}{ Group } & Number of animals & Mean & SD & P value \\
\hline Control & 6 & 1.7067 & 0.06506 & \multirow{2}{*}{0.423} \\
\cline { 1 - 4 } Treated & 6 & 1.5900 & 0.05508 & \\
\cline { 1 - 4 } Rehabilitated & 6 & 1.6867 & 0.06524 & \\
\hline
\end{tabular}

Table (1b): Shows the results of Post Hoc tests between controls, treated and rehabilitated groups.

\begin{tabular}{|l|c|c|}
\hline \multicolumn{1}{|c|}{ Group } & Group & P value \\
\hline Control & Treated & 0.087 \\
\hline Control & Rehabilitated & 0.746 \\
\hline Treated & Rehabilitated & 0.144 \\
\hline
\end{tabular}

$P$ value $<0.05$ is significant.

Table (2a): Shows means of testicular volume $(\mathrm{ml})$ and their statistical analysis for control, cyclophosphamide treated and rehabilitated groups.

\begin{tabular}{|l|c|c|c|c|}
\hline \multicolumn{1}{|c|}{ Group } & Number of animals & Mean & SD & P value \\
\hline Control & 6 & 1.4767 & 0.02517 & \multirow{2}{*}{$0.000^{* *}$} \\
\cline { 1 - 4 } Treated & 6 & 0.9767 & 0.03547 & \\
\cline { 1 - 4 } Rehabilitated & 6 & 1.3567 & 0.02618 & \\
\hline
\end{tabular}

Table (2b): Shows the results of Post Hoc tests between controls, treated and rehabilitated groups.

\begin{tabular}{|l|c|c|}
\hline \multicolumn{1}{|c|}{ Group } & Group & P value \\
\hline Control & Treated & $0.036^{*}$ \\
\hline Control & Rehabilitated & 0.320 \\
\hline Treated & Rehabilitated & $0.023^{*}$ \\
\hline
\end{tabular}

$P$ value $<0.05$ is significant.

$P$ value $<0.001$ is highly significant.

*Indicates significant difference. ** Indicates highly significant difference.

Table (3a): Shows means of seminiferous tubules diameter in microns 
and their statistical analysis for control, cyclophosphamide treated and rehabilitated groups.

\begin{tabular}{|l|c|c|c|c|}
\hline \multicolumn{1}{|c|}{ Group } & Number of animals & Mean & SD & P value \\
\hline Control & 6 & 297.9600 & 1.71415 & \multirow{2}{*}{$0.016^{*}$} \\
\cline { 1 - 4 } Treated & 6 & 260.3133 & 14.39733 & \\
\cline { 1 - 4 } Rehabilitated & 6 & 290.5400 & 13.97221 & \\
\cline { 1 - 3 } & & & & \\
\end{tabular}

Table (3b): Shows the results of Post Hoc tests between controls, treated and rehabilitated groups.

\begin{tabular}{|l|c|c|}
\hline \multicolumn{1}{|c|}{ Group } & Group & P value \\
\hline Control & Treated & $0.041^{*}$ \\
\hline Control & Rehabilitated & 0.779 \\
\hline Treated & Rehabilitated & $0.035^{*}$ \\
\hline
\end{tabular}

$\mathrm{P}$ value $<0.05$ is significant. * Indicates significant difference.

Table (4a): Shows means of volume proportions of seminiferous tubules and their statistical analysis for control, cyclophosphamide treated and rehabilitated groups.

\begin{tabular}{|l|c|c|c|c|}
\hline \multicolumn{1}{|c|}{ Group } & Number of animals & Mean & SD & P value \\
\hline Control & 6 & 90.1633 & 3.12897 & $0.000^{* *}$ \\
\cline { 1 - 4 } Treated & 6 & 59.5800 & 0.76492 & \\
\cline { 1 - 3 } Rehabilitated & 6 & 88.0867 & 0.74333 & \\
\hline
\end{tabular}

Table (4b): Shows the results of Post Hoc tests between controls, treated and rehabilitated groups.

\begin{tabular}{|l|c|c|}
\hline \multicolumn{1}{|c|}{ Group } & Group & P value \\
\hline Control & Treated & $0.000^{* *}$ \\
\hline Control & Rehabilitated & 0.231 \\
\hline Treated & Rehabilitated & $0.000^{* *}$ \\
\hline
\end{tabular}

$P$ value $<0.05$ is significant.

*Indicates significant difference.
$\mathrm{P}$ value $<0.001$ is highly significant. ** Indicates highly significant difference.

Table (5a): Shows means of seminiferous epithelial height in microns 
and their statistical analysis for control, cyclophosphamide treated and rehabilitated groups.

\begin{tabular}{|l|c|c|c|c|}
\hline \multicolumn{1}{|c|}{ Group } & Number of animals & Mean & SD & P value \\
\cline { 1 - 4 } Control & 6 & 90.8175 & 2.06107 & \multirow{2}{*}{$0.011^{*}$} \\
\cline { 1 - 4 } Treated & 6 & 74.1300 & 10.92894 & \\
\cline { 1 - 4 } Rehabilitated & 6 & 75.1025 & 3.60439 & \\
\cline { 1 - 3 } & & & \multicolumn{2}{c}{} \\
\end{tabular}

Table (5b): Shows the results of Post Hoc tests between controls, treated and rehabilitated groups.

\begin{tabular}{|l|c|c|}
\hline \multicolumn{1}{|c|}{ Group } & Group & P value \\
\hline Control & Treated & $0.039^{*}$ \\
\hline Control & Rehabilitated & 0.940 \\
\hline Treated & Rehabilitated & $0.031^{*}$ \\
\hline
\end{tabular}

$\mathrm{P}$ value $<0.05$ is significant. * Indicates significant difference.

Table (6a): Shows means of Sertoli cell numbers per cross section of a seminiferous tubule and their statistical analysis for control, cyclophosphamide treated and rehabilitated groups.

\begin{tabular}{|l|c|c|c|c|}
\hline \multicolumn{1}{|c|}{ Group } & Number of animals & Mean & SD & P value \\
\hline Control & 6 & 16.000 & 1.76000 & \multirow{2}{*}{0.635} \\
\cline { 1 - 4 } Treated & 6 & 14.7967 & 1.92500 & \\
\cline { 1 - 4 } Rehabilitated & 6 & 15.1967 & 0.30501 & \\
\hline
\end{tabular}

Table (6b): Shows the results of Post Hoc tests between controls, treated and rehabilitated groups.

\begin{tabular}{|l|c|c|}
\hline \multicolumn{1}{|c|}{ Group } & Group & P value \\
\hline Control & Treated & 0.76 \\
\hline Control & Rehabilitated & 0.56 \\
\hline Treated & Rehabilitated & 0.85 \\
\hline
\end{tabular}

$P$ value $<0.05$ is significant.

Table (7a): Shows means of A-spermatogonia numbers per cross 
section of a seminiferous tubule and their statistical analysis for control, cyclophosphamide treated and rehabilitated groups.

\begin{tabular}{|l|c|c|c|c|}
\hline \multicolumn{1}{|c|}{ Group } & Number of animals & Mean & SD & P value \\
\hline Control & 6 & 18.4967 & 2.40500 & \multirow{2}{*}{$0.000^{* *}$} \\
\cline { 1 - 4 } Treated & 6 & 7.1967 & 0.79501 & \\
\cline { 1 - 3 } Rehabilitated & 6 & 14.5967 & 1.75500 & \\
\cline { 1 - 3 } & & & & \\
\hline
\end{tabular}

Table (7b): Shows the results of Post Hoc tests between controls, treated and rehabilitated groups.

\begin{tabular}{|c|c|c|}
\hline Group & Group & P value \\
\hline Control & Treated & $0.002^{*}$ \\
\hline Control & Rehabilitated & 0.95 \\
\hline Treated & Rehabilitated & $0.03^{*}$ \\
\hline
\end{tabular}

$P$ value $<0.05$ is significant.

$P$ value $<0.001$ is highly significant.

*Indicates significant difference. ** Indicates highly significant difference.

Table (8a): Shows means of B-spermatogonia numbers per cross section of a seminiferous tubule and their statistical analysis for control, cyclophosphamide treated and rehabilitated groups.

\begin{tabular}{|l|c|c|c|c|}
\hline \multicolumn{1}{|c|}{ Group } & Number of animals & Mean & SD & P value \\
\hline Control & 6 & 21.1400 & 0.59808 & \multirow{2}{*}{$0.003^{*}$} \\
\cline { 1 - 4 } Treated & 6 & 14.7467 & 0.26388 & \\
\cline { 1 - 4 } Rehabilitated & 6 & 17.8267 & 2.13500 & \\
\cline { 1 - 3 } & & & & \\
\hline
\end{tabular}

Table (8b): Shows the results of Post Hoc tests between controls, treated and rehabilitated groups.

\begin{tabular}{|l|c|c|}
\hline \multicolumn{1}{|c|}{ Group } & Group & P value \\
\hline Control & Treated & $0.012^{*}$ \\
\hline Control & Rehabilitated & 0.67 \\
\hline Treated & Rehabilitated & $0.013^{*}$ \\
\hline
\end{tabular}

$\mathrm{P}$ value $<0.05$ is significant. $\quad *$ Indicates significant difference.

Table (9a): Shows means of pachytene primary spermatocytes numbers 
per cross section of a seminiferous tubule and their statistical analysis for control, cyclophosphamide treated and rehabilitated groups.

\begin{tabular}{|l|c|c|c|c|}
\hline \multicolumn{1}{|c|}{ Group } & Number of animals & Mean & SD & P value \\
\hline Control & 6 & 50.800 & 2.5400 & \multirow{2}{*}{$0.000^{* * *}$} \\
\cline { 1 - 4 } Treated & 6 & 36.1167 & 0.36501 & \\
\cline { 1 - 4 } Rehabilitated & 6 & 46.0067 & 2.76500 & \\
\hline
\end{tabular}

Table (9b): Shows the results of Post Hoc tests between controls, treated and rehabilitated groups.

\begin{tabular}{|l|c|c|}
\hline \multicolumn{1}{|c|}{ Group } & Group & P value \\
\hline Control & Treated & $0.015^{*}$ \\
\hline Control & Rehabilitated & 0.86 \\
\hline Treated & Rehabilitated & $0.022^{*}$ \\
\hline
\end{tabular}

$P$ value $<0.05$ is significant. $\quad P$ value $<0.001$ is highly significant.

*Indicates significant difference. ** Indicates highly significant difference.

Table (10a): Shows means of rounded spermatid cell numbers per cross section of a seminiferous tubule and their statistical analysis for control, cyclophosphamide treated and rehabilitated groups.

\begin{tabular}{|l|c|c|c|c|}
\hline \multicolumn{1}{|c|}{ Group } & Number of animals & Mean & SD & P value \\
\cline { 1 - 4 } Control & 6 & 155.5000 & 18.66000 & \multirow{2}{*}{$0.023^{*}$} \\
\cline { 1 - 4 } Treated & 6 & 115.2967 & 5.76500 & \\
\cline { 1 - 4 } Rehabilitated & 6 & 139.2433 & 10.10135 & \\
\cline { 1 - 3 } & & & & \\
\hline
\end{tabular}

Table (10b): Shows the results of Post Hoc tests between controls, treated and rehabilitated groups.

\begin{tabular}{|l|c|c|}
\hline \multicolumn{1}{|c|}{ Group } & Group & P value \\
\hline Control & Treated & $0.01^{*}$ \\
\hline Control & Rehabilitated & 0.98 \\
\hline Treated & Rehabilitated & $0.028^{*}$ \\
\hline
\end{tabular}

$\mathrm{P}$ value $<0.05$ is significant. * Indicates significant difference.

Table (11a): Shows means of volume proportions of interstitial spaces 
and their statistical analysis for control, cyclophosphamide treated and rehabilitated groups.

\begin{tabular}{|l|c|c|c|c|}
\hline \multicolumn{1}{|c|}{ Group } & Number of animals & Mean & SD & P value \\
\hline Control & 6 & 9.8267 & 3.12897 & \multirow{2}{*}{$0.000^{* *}$} \\
\cline { 1 - 4 } Treated & 6 & 40.4100 & 0.76492 & \\
\cline { 1 - 4 } Rehabilitated & 6 & 11.9033 & 0.74333 & \\
\hline
\end{tabular}

Table (11b): Shows the results of Post Hoc tests between controls, treated and rehabilitated groups.

\begin{tabular}{|l|c|c|}
\hline \multicolumn{1}{|c|}{ Group } & Group & P value \\
\hline Control & Treated & $0.000^{* *}$ \\
\hline Control & Rehabilitated & 0.231 \\
\hline Treated & Rehabilitated & $0.000^{* *}$ \\
\hline
\end{tabular}

$\mathrm{P}$ value $<0.05$ is significant. $\quad \mathrm{P}$ value $<0.001$ is highly significant.

$*$ Indicates significant difference. $\quad * *$ Indicates highly significant difference.

Table (12a): Means of Leydig cell number per high power field and their statistical analysis for control, cyclophosphamide treated and rehabilitated animals.

\begin{tabular}{|l|c|c|c|c|}
\hline \multicolumn{1}{|c|}{ Group } & Number of animals & Mean & SD & P value \\
\hline Control & 6 & 11.7500 & 1.50000 & 0.184 \\
\cline { 1 - 4 } Treated & 6 & 10.0000 & 0.81650 & \\
\cline { 1 - 3 } Rehabilitated & 6 & 10.7500 & 1.25831 & \\
\cline { 1 - 3 } & & &
\end{tabular}

Table (12b): Shows the results of Post Hoc tests between controls, treated and rehabilitated groups.

\begin{tabular}{|l|l|l|}
\hline \multicolumn{1}{|c|}{ Group } & \multicolumn{1}{c|}{ Group } & \multicolumn{1}{c|}{ P value } \\
\hline Control & Treated & 0.074 \\
\hline Control & Rehabilitated & 0.278 \\
\hline Treated & Rehabilitated & 0.409 \\
\hline
\end{tabular}

$P$ value $<0.05$ is significant. 
Assiut Vet. Med. J. Vol. 55 No. 121 April 2009 
Assiut Vet. Med. J. Vol. 55 No. 121 April 2009

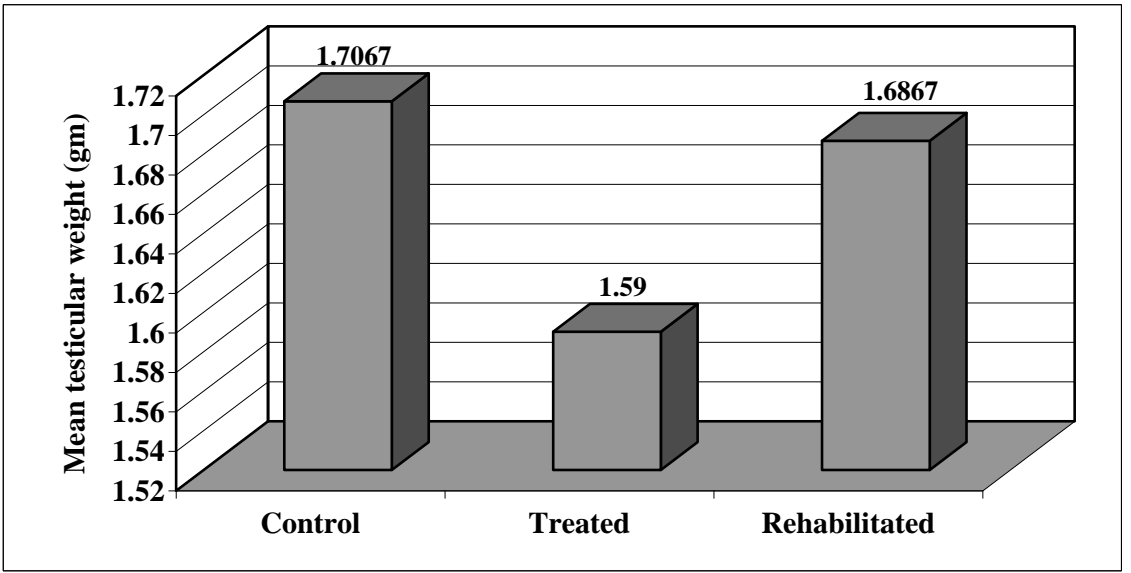

2

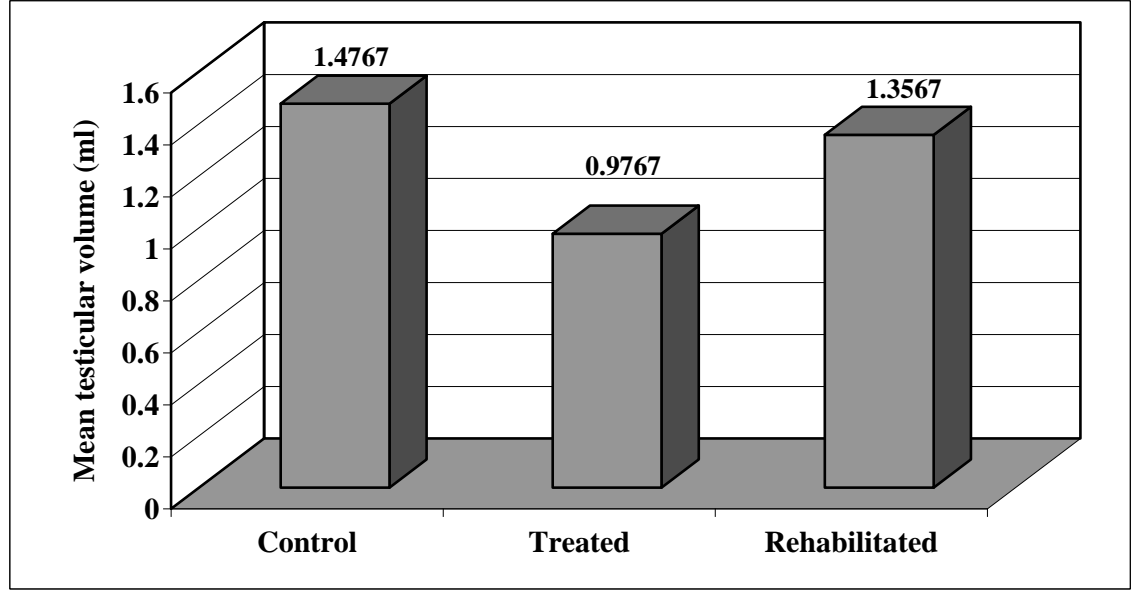

3

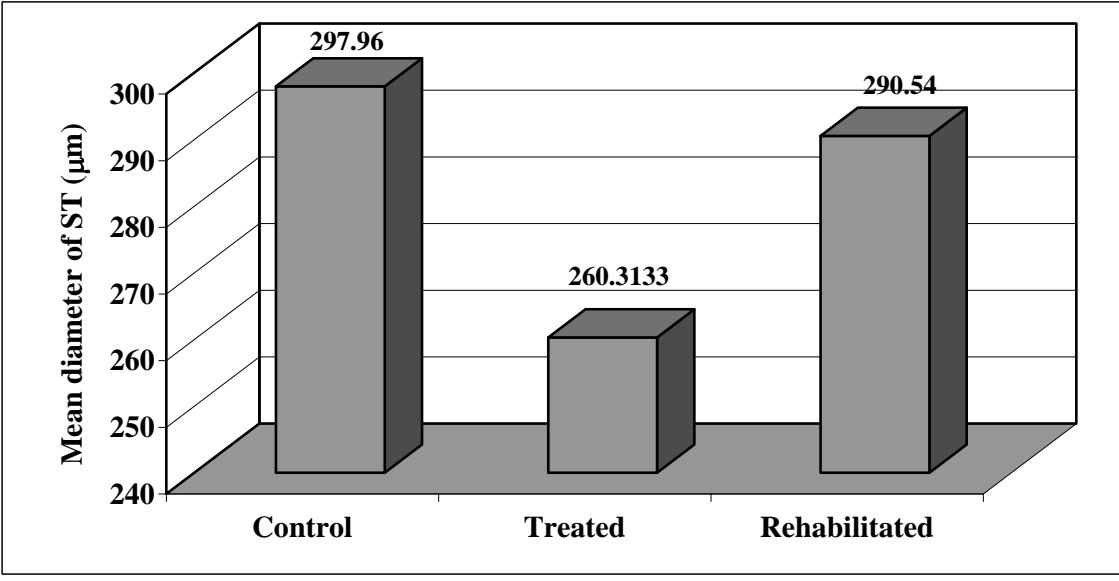

4 


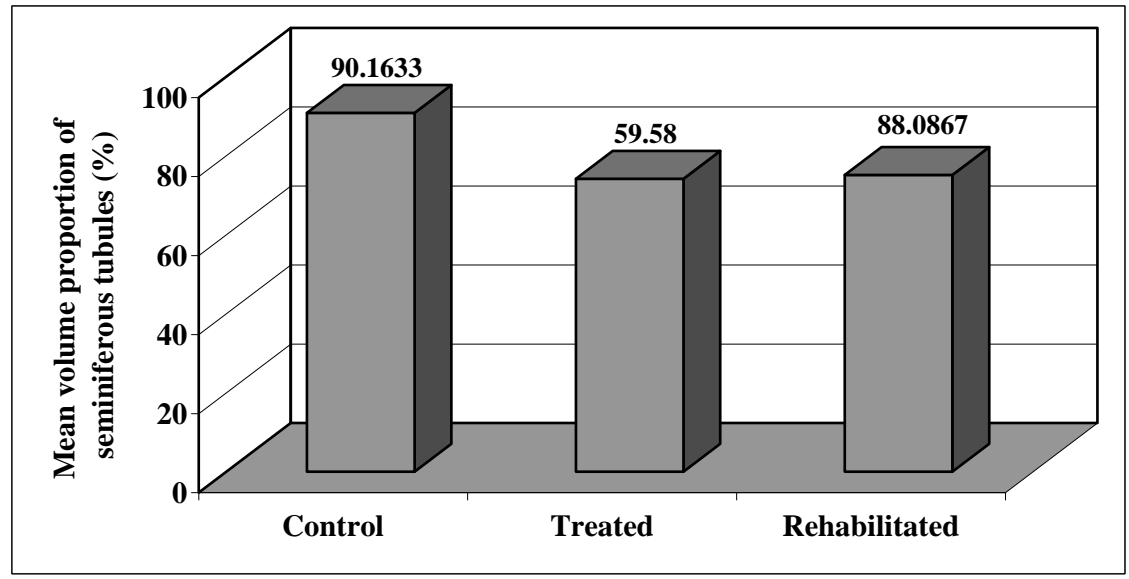

5

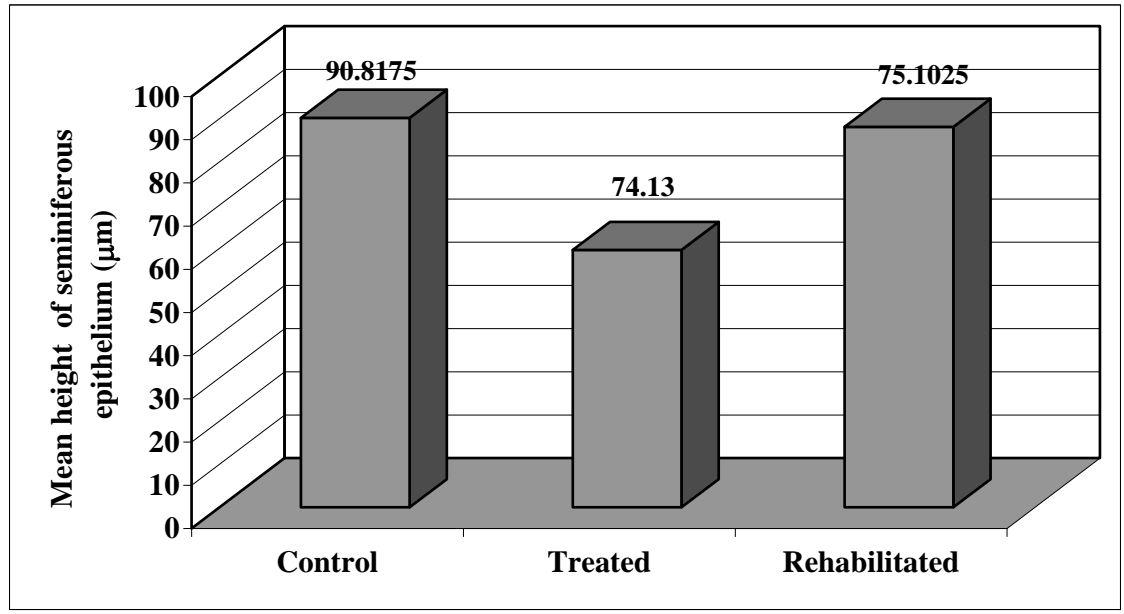

6

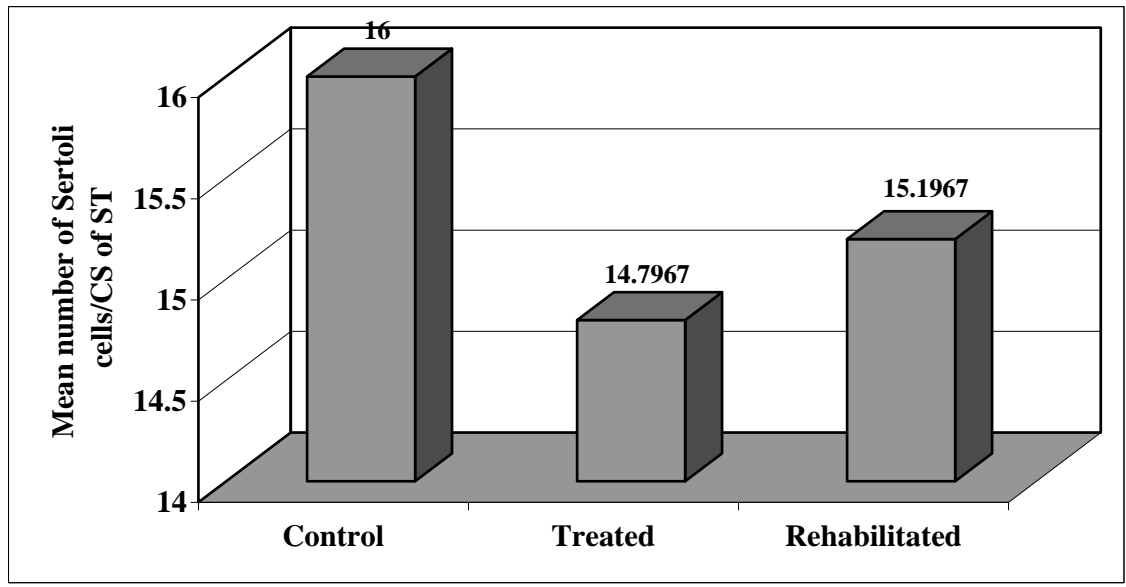

7 


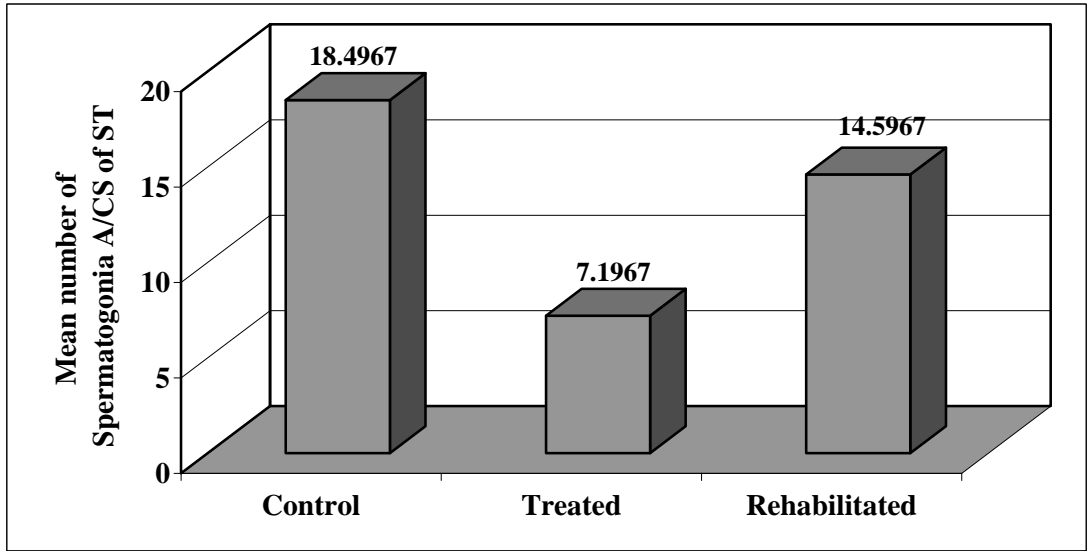

8

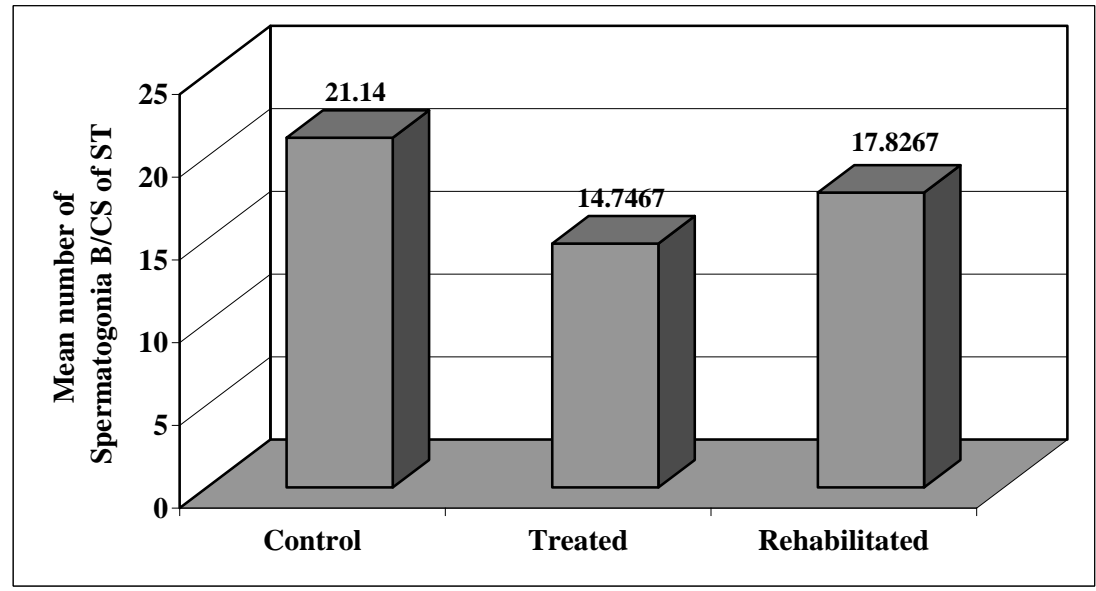

9

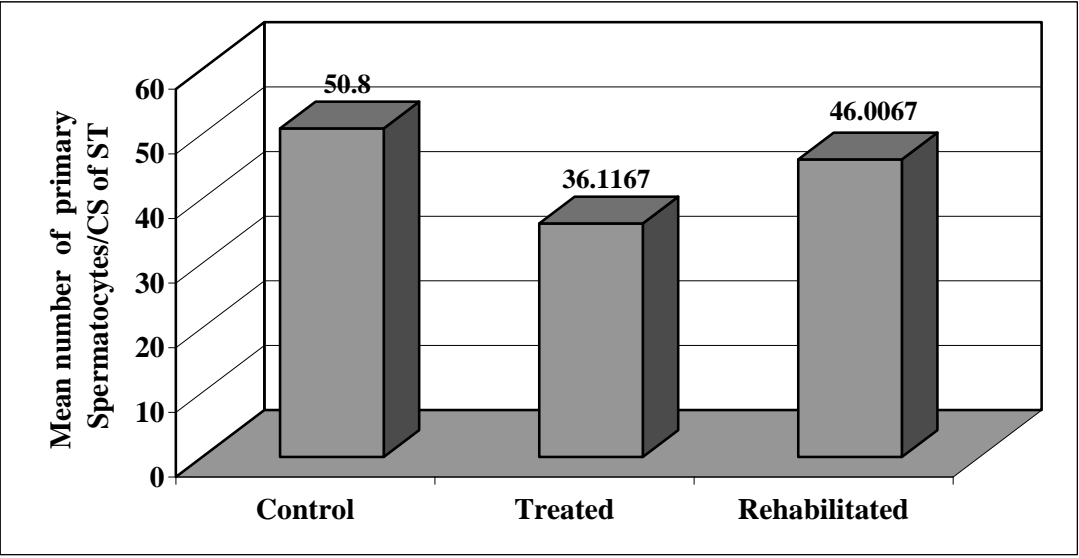


Assiut Vet. Med. J. Vol. 55 No. 121 April 2009

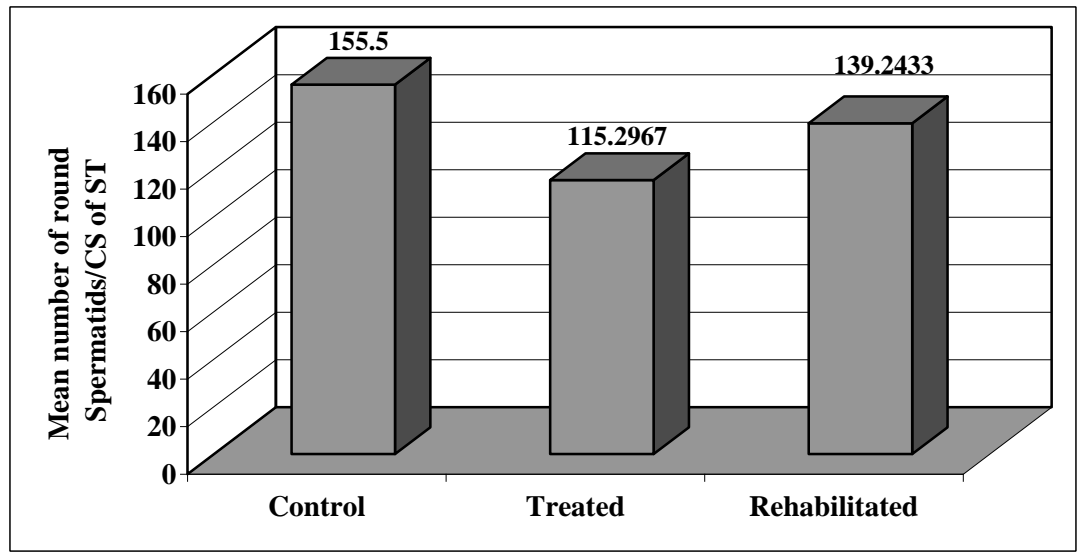

11

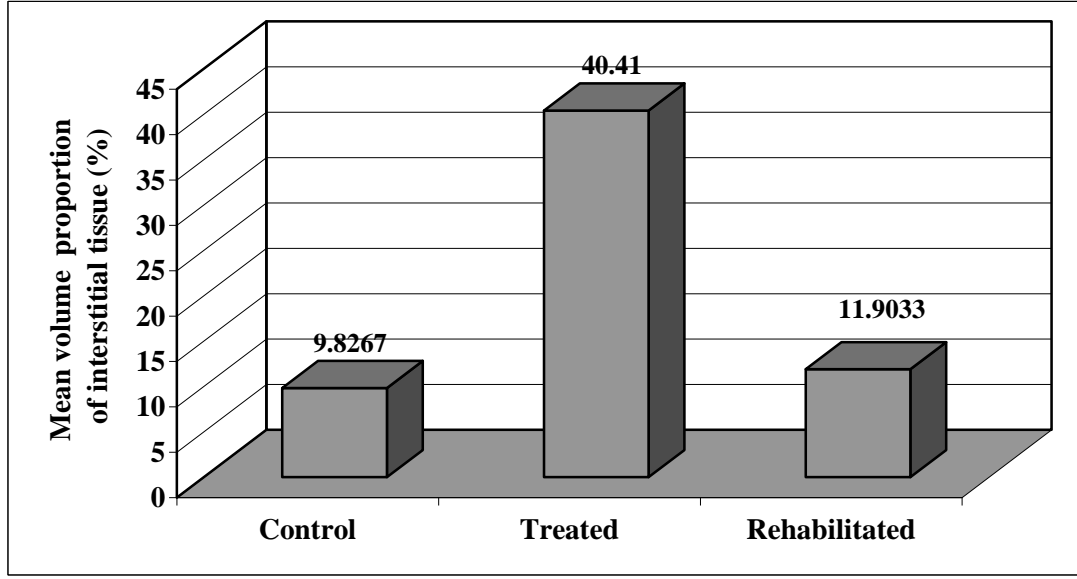

12

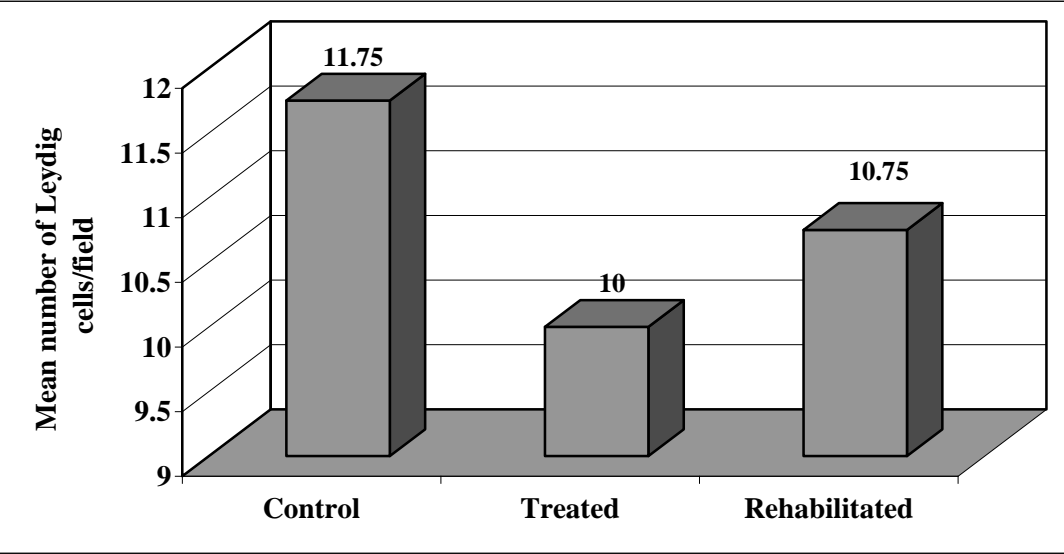




\section{LEGENDS:}

Fig. 1: Semithin sections from testes of adult albino rats.

A: Testis from control rats showed normal features of seminiferous tubules (St), lined with Sertoli cells (S) and organized germinal epithelium at different stages of maturation and normal interstitial tissue (i) between the tubules, containing blood vessels (BV) and interstitial cells (*). Toluidine blue $\mathrm{x}$ 250

B: Testis from cyclophosphamide treated rats revealed irregular malformed seminiferous tubules $(\uparrow)$ with impaired germinal epithelium, multiple degenerative vacuoles (V) and dark degenerated cells $(*)$ between the disorganized and dissociated germ cells. Notice the marked interstitial tissue oedema with multiple blood vessels (BV). Toluidine blue x 250

$\mathrm{C}$ : The testis from rehabilitated rats showed nearly normal seminiferous tubules (St) lined with normal organized epithelium and normal sized interstitial tissue in between with multiple blood vessels (BV) and Leydig cells (L). Notice irregularity of basement membrane (BM) and basal vacuoles (V) of some tubules. Toluidine blue x 250

Fig. 2: Mean of testicular weight of control animals compared to cyclophosphamide treated and rehabilitated ones.

Fig. 3: Mean of testicular volume of control animals compared to cyclophosphamide treated and rehabilitated animals.

Fig. 4: Mean of diameter of seminiferous tubules of control animals compared to cyclophosphamide treated and rehabilitated animals.

Fig. 5: Mean of volume proportions of seminiferous tubules of control animals compared to cyclophosphamide treated and rehabilitated animals.

Fig. 6: Mean of seminiferous epithelial height of control animals compared to cyclophosphamide treated and rehabilitated animals.

Fig. 7: Mean of numbers of Sertoli cells per cross section of a seminiferous tubule of control animals compared to cyclophosphamide treated and rehabilitated animals.

Fig. 8: Mean of numbers of type A-spermatogonia per cross section of a seminiferous tubule of control animals compared to cyclophosphamide treated and rehabilitated animals. 
Fig. 9: Mean of numbers of type B-spermatogonia per cross of seminiferous tubule of control animals compared to cyclophosphamide treated and rehabilitated animals.

Fig. 10: Mean of numbers of pachytene primary spermatocytes per cross section of a seminiferous tubule of control animals compared to cyclophosphamide treated and rehabilitated animals.

Fig. 11: Mean of numbers of round spermatids per cross section of a seminiferous tubule of control animals compared to cyclophosphamide treated and rehabilitated animals.

Fig. 12: Mean of volume proportions of interstitial spaces of control animals compared to cyclophosphamide treated and rehabilitated animals.

Fig. 13: Shows mean of Leydig cell number per high power field for control animals compared to cyclophosphamide treated and rehabilitated animals.

\section{DISSCUSION}

\section{General consideration}

Effective cancer chemotherapy as well as immunosuppressive therapy with Cyclophosphamide (CP) is severely limited due to its reproductive toxicity in various species (Fraiser et al., 1991). Cyclophosphamide, as an alkylating agent is extremely dangerous to the germinal ephitelium, whose germ cells are killed or damaged at the stage of differentiating spermatogonia (Meistrich et al., 1982). High doses of this alkylating agent can cause azoospermia for more than 3 years and a cumulative dose leads to serious and sometimes irreversible damage to spermatogenesis and results in male infertility (Byrne, et al., 1987; Schrader et al., 2001). Long-term treatment with CP injures progeny outcomes, decreases the weight of the reproductive organs, and impairs fertility (Trasler et al., 1986; Higuchi et al., 1995; Oh et al., 2007) due to genotoxic damage (Schimenti et al., 1997; Barton et al. 2003) which may interfere with germ cell generation and maturation or lead to the production of non-functional spermatozoa (Iammarrone et al., 2003). Apart from reduced spermatogenesis, CP treatment is associated with increased levels of follicular stimulating hormone (FSH) and low levels of testosterone (Hoorweg-Nijman et al., 1992).

Cyclophosphamide is one of the most frequently used antitumor agents and an essential component of many effective drug combinations for the treatment of a broad spectrum of human cancers (Wang, et al., 
2007). As an alkylating agent, CP prevents cell division and proliferation due to its DNA damaging effect, primarily by cross-linking DNA strands (Crook et al., 1986 \& Andreson et al., 1995) before pachytene stage of meiosis during spermatogenesis (Schimenti et al., 1997). CP exposure affected gene expression in all cell types during spermatogenesis, but most dramatically in round spermatids and pachytene spermatocytes [Aguilar-Mahecha et al., 2001 \& 2002). Epididymis spermatozoa, testicular spermatids and early spermatids, respectively were the most sensitive to damage induction of CP (Preston et al., 1995\& Chamorro-Cevallos et al., 2008).

Gonadotoxicity of most alkylating agents, especially $\mathrm{CP}$, has been widely described in the literature of Shafford et al., 1993; Kenney et al., 2001 and Ridola et al., 2009. Histological changes and quantitative reduction of spermatogenic cells in the testis of rats after repeated administration of $\mathrm{CP}(100 \mathrm{mg} / \mathrm{kg} /$ week $)$ for five consecutive weeks in the present study were an indication of $\mathrm{CP}$ drug toxicity.

\section{Histological remarks}

Morphological alterations were produced in the seminiferous tubules, treated with CP (Kaur et al., 1997; Meistrich, 1998; Selvakumar et al., 2006a; Elangovan et al., 2006 \& Tripathi and Jena, 2008). Histological examination, in the present study, revealed shrunken malformed seminiferous tubules with less mature sperms and thickened irregular basement membrane, disruptions of the normal spermatogenic architecture with degenerative vacuolations and impaired spermatogenesis in treated group compared to that in the control. CP induced degenerative changes in the germ cells in form of darkly stained nuclei with fragmented DNA, as well as cytoplasmic shrinkage with degenerative vacuoles and loss of cell integrity. Type A spermatogonia were predominantly affected, that they were rarely seen or replaced by degenerative basal vacuoles. Round spermatids were also damaged and showed loss of integrity, marked irregularity and intense degenerative structural changes. The interstitial spaces between the seminiferous tubules showed marked oedema with moderately dilated blood vessels and apparently less affected Leydig cells. However, Elangovan et al., (2006) observed tubules with qualitatively normal spermatogenesis in mice treated with low dose of cyclophosphamide even when exposed for longer duration.

\section{Quantitative studies:}

\subsection{Testicular weight}

Trasler et al. (1986) reported that multiple low dose treatment with $\mathrm{CP}$ leads to decrease in the weight of reproductive organs. In this 
sense and in agreement with the studies of (Rajinder et al., 1997; Das et al., 2002; Selvakumar et al., 2006b; Elangovan et al., 2006 \& Tripathi and Jena, 2008), repeated administration of CP (100 mg/kg/week) for five consecutive weeks, in the present study decreases the testes weight and volume in the treated rat group. The testes of CREM gene-deficient mice induced by CP display a reduction of $20-25 \%$ in their weight (Oh et al., 2007). CP administration (100 mg/kg body weight, for five consecutive days) showed decreased testis and cauda epididymal weight and sperm count in albino rats (Kaur et al., 1997). Elangovan et al., (2006) showed significant decrease in the weight of the testis with all doses of cyclophosphamide $(50-200 \mathrm{mg} / \mathrm{kg}), 1^{\text {st }}$ week after last injection, whereas, after $5^{\text {th }}$ week of last injection, significant reduction was observed only in $200 \mathrm{mg} / \mathrm{kg}$ dose of cyclophosphamide in treated mice when compared to the control. The weight of the testis largely depends on the mass of the differentiated spermatogenic cells and a reduction in testis weight can be attributed due to severe decrease in spermatogenic as well as leydig cells and sperm production, as evident from flowcytometric analysis (Katoh et al., 2002; Elangovan et al., 2006 \& Tripathi and Jena, 2008).

Testicle weight improvement observed in rehabilitated group after $6^{\text {th }}$ week of last CP injection, when compared to the treated group. The recovery in testicular weight may attribute to restoration of spermatogenic cell number and reversed $\mathrm{CP}$ - induced gonadal damage over time. Elangovan et al., (2006) found recovery in weight of the testis and epididymis after $5^{\text {th }}$ week of treatment except in mice treated with high dose of cyclophosphamide $(200 \mathrm{mg} / \mathrm{kg}$ ) and suggested restoration of testis weight with restoration of sperm number. Chamorro-Cevallos et al., (2008) attributed testicle weight improvement in Spirulina (SP) treated groups to improved sperm production. It was found that Astaxanthin (AST) treatment (Tripathi and Jena, 2008), Lipoic acid pretreatment (Selvakumar et al., 2006b) substantially buffered CP induced testicular damage and improved the testis weight and sperm count.

\subsection{Seminiferous tubules}

Decrease in the size and diameter of seminiferous tubules provides further evidence in support of the existence of seminiferous tubule damage induced by $\mathrm{CP}$. The present results, in coinciding the previous ones of Galal et al., (1994); Selvakumar et al., (2006a); Tripathi and Jena, (2008) demonstrated a significant reduction in the diameter and volume proportions of the seminiferous tubules in the 
treated rats compared to the control. Moreover, the size and number of the seminiferous tubules decreased with increasing concentration of $\mathrm{CP}$ (Elangovan et al., 2006; Tripathi and Jena, 2008). A marked improvement in diameter and volume proportions of the seminiferous tubules, observed in this study, in rehabilitated rats compared to treated ones may be attributed to recovery in the morphological alterations induced by $\mathrm{CP}$ in the seminiferous tubules during rehabilitation time.

Testicular biopsies from males exposed to cyclophosphamide showed an absence of spermatogenic cycles in their testicular tissue (Howell and Shalet, 1988) and depletion of the germinal epithelium, which is essential for normal spermatogenesis (Uderzo et al., 1984; Kenney et al., 2001). Supporting to these data, the present study demonstrated a significant decrease in the germinal epithelium height within the seminiferous tubule in $\mathrm{CP}$ treated rat group compared to control rats. These findings are confirmed by clinical investigations of men exposed to CP and show a high incidence of azoospermia (Kumar et al., 1972), also male rats exposed to this drug have oligozospermia and azoospermia (Kaur et al., 1997). Considerable evidence suggests that depletion of germinal epithelium leads to decrease in secretion of inhibin from Sertoli cells with subsequent elevation of serum FSH levels (Ahmad et al., 2008). Decrease in the germinal epithelium height may be due to the cytotoxic and genotoxic effect of $\mathrm{CP}$ on the germ cells as well as reduced spermatogenesis.

\subsection{Sertoli cells}

Although germinal epithelium is particularly susceptible to injury by CP toxicity due to its high mitotic rate, Sertoli's cell function is often preserved due to its very low proliferation index (Ahmad et al., 2008). Farily et al., (1972); Etteldorf et al., (1976) and Uderzo et al., (1984) reported decreased spermatogenic cells with preservation of Sertoli cells in the testis of CP treated patients and observed seminiferous tubules lined only by Sertoli cells with absent germinal cells. This results altered spermatogenesis, leaving testosterone function unaffected (Fegan and Lipshultz, 1998). In line with previous studies, this literature survey revealed an insignificant decrease in number of Sertoli cells in treated group with respect to the control and nearly restored to normal levels in rehabilitated rat group. Martinova et al., (2006) reported a non specific reaction in Sertoli cells induced by CP in mouse testis, while, Selvakumar et al., (2006a) observed damaged Sertoli cells in rat after CP exposure; however, Galal et al., (1994) revealed a significant decrease in Sertoli cell number. It was reported 
that chronic cyclophosphamide treatment alters spermatogenesis (Elangovan et al., 2006; Tripathi and Jena, 2008).

\subsection{Spermatogonia-A}

It was reported that chronic cyclophosphamide treatment alters spermatogenesis (Elangovan et al., 2006; Tripathi and Jena, 2008). Spermatogenesis is the development of mature haploid spermatozoa from diploid spermatogonial stem cells. This development includes a sequence of cytological and biochemical events, including mitotic and meiotic divisions, which lead to drastic changes in cellular morphology and physiology (Russell et al., 1990 and Suter et al., 1997). In the testis, cyclophosphamide disrupts meiotic events during spermatogenesis before pachytene stage thus emphasizing the potential for adverse progeny outcomes due to genotoxic damage. To maintain genomic stability, eukaryotic cells respond to genetic damage by arresting or delaying cell cycle progression. Such delay, allows for the activation of DNA repair mechanisms, or when the damage is too overwhelming, of cell death pathways (Sancar et al., 2004). The morphometric study of different stages in spermatogenic cycle indicates that testicular toxicity can be detected from day 7 even after a single oral administration of $\mathrm{CP}$ $(100 \mathrm{mg} / \mathrm{kg}$ ) in rat (Matsui et al., 1995).

Spermatogonia are target cells of $\mathrm{CP}$ in the male reproductive system. Studies on rodents have shown that the damaging effects of chemotherapy occur at the level of A-spermatogonia differentiation (Meistrich et al., 1998). Spermatogonia are diploid elements, small proportion of all the germinal cells involved in spermatogenesis. Cytotoxic agents and radiation effects cause blockage of spermatogenesis by killing stem cells (spermatogonia) (Clopi et al., 2004). This study demonsrated that spermatogonia $-\mathrm{A}$ are the target cells in the testis for the damaging effect of $\mathrm{CP}$ as indicated by their marked degenerative changes on histological examination and the highly significant reduction in their number, morphometrically in the treated rat group compared to the control. This is in consistent with the reports of Russell and Russell (1991); Takahashi and Matsui (1993) and Matsui et al., (1995) in rat and with Lu and Meistrich (1979) and Da Cuncha et al., (1987) in mice, who demonstrated that spermatogonia type A is the first target cell of CP toxicity in the testis. This is most probably due to the high mitotic activity of spermatogonia $-\mathrm{A}$, that make them vulnerable to the toxic effect of CP. On histological quantitative evaluation, Matsui et al., (1995); Matsumoto et al., (2000); fukushima et al., (2005); Elangovan et al., (2006) and Tripathi and Jena, (2008) reported 
consistent decrease in the number of spermatogonia- A after CP exposure. Watanabe et al., (2000) reported that spermatogonia type A decreased significantly in all stages of seminiferous tubules examined after CP administration. It has already been reported that CP induced apoptosis in a stage specific manner in spermatogonia and spermatocyte of rat testes (Cai et al., 1997), mainly due to the increased oxidative stress which results in the lipid peroxidation and affects the membrane integrity and fluidity (Tripathi and Jena, 2008).

Elangovan et al., (2006) literature revealed that some cells of spermatogonia (sperm stem cells) are resistant to damage with high dose of CP even after a period of 5 weeks. Inactivation of only a fraction of these sperm stem cells in a given tubule may have a disproportionately larger effect on spermatogenesis and hence the decrease in sperm counts. Damage to spermatogonia can lead to different degrees of oligospermia, and the death of stem spermatogonia can result in azoospermia. The duration of azoospermia appears to be related to the proportion of stem cells killed; if all stem cells are killed, the azoospermia will be irreversible (Meistrich, 1986). Azoospermia lasting only weeks to months reflects transient damage to late differentiating spermatogonia whereas a delay of years for recovery points to widespread damage of even early spermatogonia and stem cells in patients treated with CP (Ahmad et al., 2008). Interestingly, an increase in external malformations and growth retardation was produced in progeny sired by germ cells first exposed to $\mathrm{CP}$ as spermatogonia that significantly persisted to the F2 generation (Hales et al., 1992; Hales et al., 2005).

The presence of stem cells is a prerequisite for being able to stimulate recovery in spermatogenesis. If certain cumulative cytostatic doses are not surpassed, these stem cells (spermatogonia- A) survive chemotherapy and form the basis for the recovery of spermatogenesis and a long time can be needed to convert them to spermatozoa (Schrader et al., 2001). The present analysis revealed a significant increase in number of spermatogonia -A cells in rehabilitated group compared to the treated one. Spermatogenesis fails to recover not because stem spermatogonia are killed, but rather because surviving stem spermatogonia fail to differentiate (Kangasniemi et al., 1996). The increase in the FSH levels may contribute to the inhibition of spermatogonial differentiation (McLachlan et al., 2002; Elangovan et al., 2006). Meistrich, (1998) subsequently achieved recovery of Aspermatogonia differentiation by administering testosterone or GnRH agonists. Tripathi and Jena, (2008) explore that the reduction in number 
of spermatogonia induced by $\mathrm{CP}$ can be prevented by Astaxanthin (AST) treatment.

\subsection{Spermatogonia-B}

Type B spermatogonia rapidly destroyed by cytostatics because of high mitotic activity. Lu and Meistrich, (1979) found that types A and $\mathrm{B}$ spermatogonia were sensitive to $\mathrm{CP}$ in mice and Martinova et al., (2006) showed degenerative changes in spermatogonia B induced by CP. Type B spermatogonia in the present study showed a significant reduction in number in $\mathrm{CP}$ treated group compared to the control and a significant recovery in number could be observed after 6 weeks of last injection (rehabilitated group). Watanabe et al., (2000) revealed that spermatogonia type B were affected and decreased in number after a higher dose of CP than that of type A spermatogonia and complete spermatogenesis was seen in all tubular cross sections, 56 days after $\mathrm{CP}$ injection in mice.

\subsection{Spermatocytes and spermatids}

Other cells in the seminiferous tubules such as spermatocytes and spermatids are damaged by low dose of $\mathrm{CP}$ and leads to impaired spermatogenesis. Auroux and Dulioust, (1985); Aguilar- Mahecha et al., (2001) and Satoh et al., (2002) in their morphometric evaluation of the rat testis after $\mathrm{CP}$ injection demonstrated significant decrease in the number of primary spermatocytes and spermatids. Russell and Russell, (1991) reported consistent decrease in the numbers of leptotene, zygotene and early pachytene spermatocytes in the testis of rats, 15 days after two injections, 24h apart, of $65 \mathrm{mg} / \mathrm{kg}$ of CP. Matsui et al., (1995) and Matsumoto et al., (2000) found significant decrease in the number of spermatocytes at day 14 and day 21 after one $\mathrm{CP}$ injection $(100 \mathrm{mg} / \mathrm{kg})$. Confirming to these previous data, this literature together with that of Elangovan et al., (2006) revealed significant decrease in the number of primary spermatocytes and round spermatids in the $\mathrm{CP}$ treated testes compared to the control that significantly improved to normal levels after 6 weeks of last injection, in rehabilitated group.

It has already been reported that $\mathrm{CP}$ induced apoptosis in a stage specific manner in spermatogonia and spermatocyte of rat testes (Cai et al., 1997). Aguilar- Mahecha et al., (2001) and Satoh et al., (2002) suggested that round spermatids were more vulnerable to the damaging effects induced by $\mathrm{CP}$ due to the chromatin remodeling that is takes place at this stage of spermatogenesis. A single injection of high-dose cyclophosphamide during the development of mouse spermatocytes resulted in heritable translocations (Sotomayor and Cumming, 1975) and 
increased the incidence of micronuclei (Tates, 1992) as well as genotoxic effect on the genome during meiotic prophase (Schimenti et al., 1997). Hales et al., (2005) observed increased transcript levels for $15 \%$ of the genes in round spermatids, whereas only $3 \%$ were affected in pachytene spermatocytes during acute $\mathrm{CP}$ treatment, while the predominant effect of chronic $\mathrm{CP}$ treatment was to decrease the expression of the genes studied in pachytene spermatocytes (34\%) and round spermatids $(29 \%)$.

Codrington et al., (2007) suggested that round spermatids attempt to compensate for DNA damage induced by $\mathrm{CP}$ by the expression of DNA repair genes (Aguilar-Mahecha et al., 2001). It was found that Astaxanthin (AST) treatment $(25 \mathrm{mg} / \mathrm{kg}$ ) prevents the reduction in number of spermatocytes and spermatids induced by $\mathrm{CP}$ in mice (Tripathi and Jena, 2008).

\subsection{Leydig cells}

Testicular function is influenced by both endocrine (extratesticular) and paracrine (intra-testicular) factors. The intra-testicular regulation of spermatogenesis is thought to be carried out by steroids, such as testosterone and oestradiol, which are synthesized by Leydig cells (Elangovan et al., 2006). The inhibition of spermatogenesis may be due to low levels of plasma gonadotrophin and testosterone, which are prime regulators of spermatogenesis in rats (Chowdhury, 1979) and the stimulation of recovery of spermatogenesis by $\mathrm{GnRH}$ agonists appears to be related to suppression of intra-testicular testosterone (Meistrich and Kangasniemi, 1997).

Ahmad et al., (2008) reported preservation of Leydig's cell function due to its very low proliferation index. Testicular biopsies from males exposed to cyclophosphamide show depletion of the germinal epithelium, which is essential for normal spermatogenesis, and morphologically normal Leydig cells, which function in steroidogenesis (Shalet et al., 1981). The results of above reports corroborate well with the present findings in this study, which revealed an insignificant decrease in number of Leydig cells in $\mathrm{CP}$ treated rats compared to control ones. Leydig cell damage could be explained by the lipid accumulation in the cells leading to their degeneration (Flickingerand Loving, 1976). The effect of CP on the Leydig cell morphometry could be due to the effect of $\mathrm{CP}$ on the endogenous gonadotrophin secretion and also could be due to direct effect of CP on the Leydig cells (Fichna and Malendowicz, 1975). 
The decrease of testosterone in mice was associated with the alteration of Leydig cell function. Elangovan et al., (2006) observed occasionally and moderately altered Leydig cells as shown by significant decrease in serum testosterone and $\mathrm{LH}$ levels in $\mathrm{CP}$ exposed mice. Selvakumar et al., (2006a) observed impaired spermatogenesis and Leydig cell hyperplasia in CP exposed rats. Severe decrease in spermatogenic as well as leydig cells can be attributed to the decrease in testis weight induced by CP (Katoh et al., 2002). It was reported that children who receive high dose of $\mathrm{CP}$ as part of their chemotherapy are at high risk for long-term gonadal damage including subclinical Leydig cell insufficiency and infertility (Kenney et al., 2001).

\subsection{Interstitial tissue}

Regarding the interstitial tissue, the present study revealed that the treatment of cyclophosphamide resulted in increase in the volume of interstitial spaces on the expense of seminiferous tubules. In accordance with the results of Galal et al., (1994) and Dina et al., (1996), the present findings revealed highly significant increase in the volume proportion of interstitial spaces in treated group animals compared to the control and a significant recovery in this volume proportion was observed in the rehabilitated group after 6 weeks of last CP injection. These changes could be attributed to the decrease in the perimeter and the volume proportion of seminiferous tubules (Tripathi and Jena, 2008) that resulting from reduction in the height of seminiferous epithelium and loss of the germinal epithelial cells under the toxic effect of CP.

\section{Recovery in the spermatogenesis}

Studies also have suggested that cyclophosphamide-induced gonadal damage can be reversed over time, and that gonadal damage is dose-dependent (Chamorro-Cevallos et al., 2008). There was tendency of recovery in the spermatogenesis observed at lower doses of CP treated groups as compared to higher doses (Elangovan et al., 2006). Recovery of spermatogenesis may be spontaneously achieved within 1 year in the most favorable cases, while in others it may take several years (Clopi et al., 2004). Ahmad et al., (2008) observed recovery in spermatogenesis and FSH levels to normal in patients receiving CP regimen. Meanwhile, Buchanan et al., (1975) stated that permanent sterility is not a consequence of cyclophosphamide chemotherapy and the resultant azoospermia was likely to be reversible. Oh et al., (2007) revealed that Yukmijihwang-tang (YJT) can protect against adverse reproductive effects of $\mathrm{CP}$ by inhibiting oxidative stress and enhancing spermatogenesis related with cAMP-responsive element modulator 
(CREM) gene expression in rat. Chamorro-Cevallos et al., (2008) demonstrated that Spirulina (SP) treatment substantially buffered CP induced testicular spermatogenic cell damage (Selvakumar et al., 2006 b), thereby improved sperm production. Moreover, sperm testicular extraction techniques can allow recovery of spermatogenetic cells to be used with intracytoplasmic sperm injection (ICSI) and cryopreservation of testicular tissue is also useful in prepubertal boys undergoing chemoradiotherapy (Clopi et al., 2004).

\section{Conclusion remarks}

Based on the results from the present study it is concluded that chronic cyclophosphamide treatment of male rats alters spermatogenesis via a direct effect on male germ cell number and differentiation or quality that may be considered as one of the mechanisms of action of $\mathrm{CP}$ in producing alteration in sperm number and function and hence alter fertility and progeny outcome. Marked affection in spermatogonia, spermatocytes and round spermatides reflects the susceptibility of these germ cells to $\mathrm{CP}$ insult during spermatogenesis in the testis. The tendency of recovery in the spermatogenesis observed in rehabilitated group over time reflects the important role of rehabilitation in differentiation of survive stem cell spermatogonia which may form the basis for this recovery.

\section{REFERENCES}

Aguilar-Mahecha, A.; Hales, B.F. and Robaire, B. (2001): Acute cyclophosphamide exposure has germ cell specific effects on the expression of stress response genes during rat spermatogenesis. Mol Reprod Dev. 60: 302 - 11 .

Aguilar-Mahecha, A.; Hales, B.F. and Robaire, B. (2002): Chronic cyclophosphamide treatment alters the expression of stress response genes in rat male germ cells. Biol Reprod 66: 1024 32.

Ahmad, M.; Lone, A.R.; Kuchai, S.U.; Zargar, A.H.; Aziz, S.A.; Bhat, G.M.; Banday, M.A.; Jelani, S. and Bhat, J.R. (2008): Posttreatment testicular activity in lymphoma patients. Ind J. Med. and Ped. Onc 29: 8-15.

Anderson, D.; Bishop, J.B.; Garner, R.C.; Ostrosky-Wegman, P. and Selby, P.B. (1995): Cyclophosphamide: review of its mutagenicity for an assessment of potential germ cell risks. Mutat Res 330: 115-181. 
Auroux, M. and Dulioust, E. (1985): Cyclophosphaamide in the male rat; behavioral effects in the adult offspring Behav Brain Res. 16: $25-36$.

Barton, T.S.; Wrobek, A.J.; Hill, F.S.; Robaire, B. and Hales, B.F. (2003): Numerical Chromosomal Abnormalities in Rat Epididymal Spermatozoa Following Chronic Cyclophosphamide Exposure. Biol of Reprod 69: 1150-1157.

Buchanan, J.D.; Fairly, K.F. and Barrie, J.U. (1975): Return of spermatogenesis after stopping cyclophosphamide therapy. Lancet 2: 156-157.

Byrne, J.; Mulvihill, J.J.; Myers, M.H.; Connelly, R.R.; Naughton, M.D. and Krauss, M.R., et al. (1987): Effects of treatment on fertility in long-term survivors of childhood or adolescent cancer. N. Engl J. Med. 21: 1315-21.

Cai, L.; Hales, B.F. and Robaire, B. (1997): Induction of apoptosis in the germ cells of adult male rats after exposure to cyclophosphamide. Biol Reprod 56: 1490-1497

Chamorro-Cevallos, G.; Siciliano, L.G.; Barro'n, B.L.; MadrigalBujaidar, E.; Cruz-Vega, D.E. and Pages, N. (2008): Chemoprotective effect of Spirulina (Arthrospira) against cyclophosphamide-induced mutagenicity in mice. Food and Chem. Toxicol 46: 567-574.

Chowdhury, A.K. (1979): Dependence of testicular germ cells on hormone. A quantitative study in hypophysectomized testosterone treated rats. J. Endocrinol 20: 911.

Codrington, A.M.; Hales, B.F. and Robaire, B. (2007): Chronic cyclophosphamide exposure alters the profile of rat sperm nuclear matrix proteins. Biol reprod 2: 1-31

Colpi, G.M.; Contalbi, G.F.; Nerva, F.; Sagone, P. and Piediferro, G. (2004): Testicular function following chemo-radiotherapy. European Journal of Obstetrics \& Gynecology and Reproductive Biology 113S: S2-S6.

Coork, T.K.; Souhami, R.L. and McLean, A.M. (1986): Cytotoxicity, DNA cross-linking, and single strand break induced-by activated cyclophosphamlde and acrolein in human-leukemia cells. Cancer Res. 46: 5029- 5034.

Da Cuncha, M.F.; Meistrich, M.L. and Nader, S. (1987): Absence of testicular protection by a gonadotropin-releasing hormone analogue against cyclophosphamide-induced testicular cytotoxicity in the mouse. Cancer Res., 47, 1093 - 1097. 
Das, U.B.; Mallick, M.; Debnath, J.M. and Ghosh, D. (2002): Protective effect of ascorbic acid on cyclophosphamide-induced testicular gametogenic and androgenic disorders in male rats. Asian J. Androl 4: 201-207.

Dina, M.R. (1996): Histological studies on the effects of cyclophosphamide (Endoxan) on some organs of male albino rat. M. Sc. Degree. Thesis Fac. Med. Cairo Univ.

Dollery, C. (1999): Cyclophosphamide. In: Therapeutic Drugs. Churchill Livingstone, Edinburgh p C349-C354.

Elangovan, A.N.; Chiou, C.D.T.; Tzeng, E.W. and Chu, A.B.S. (2006): Cyclophosphamide treatment causes impairment of sperm and its fertilizing ability in mice. Toxicology 222: 60-70

El-Shennawy, A.T. (1991): Stereological study on the effect of ethanol on the testis of adult albino rat. MD. Thesis, Faculty of Medicine, El-Minia University.

Etteldorf, J.N.; West, C.D.; Pitocock, J.A. and Williams, D.L. (1976): Gonadal function, testicular histology, and meiosis following cyclophosphamide therapy in patients with nephrotic syndrome. J. Pediat 88: 206- 12.

Fairly, K.F.; Barrie, J.V. and Johnson, W. (1972): Sterility and testicular atrophy related to cyclophosphamide therapy. Lancet 11: 568-9.

Fegan, J.E. and Lipshultz, L.I. (1988): M.D: Abnormalities of the testes leading to male infertility: Evaluation and diagnosis. Hospimedica 6: 33-40.

Fichna, P. and Malendowicz, L.K. (1975): A karyometric and stereologic study of the effects of gonadotrophin and testosterone on the interstitial gland of the testis of intact and endoxan treated rats. Cell Tissue Res 164: $411-24$.

Flickinger, C. and Loving, C.K. (1976): Fine structure of the testis and epididymis of rats treated with cyproteron acetate. Am. J. Anat 146: 359-365.

Flickinger, C. and Loving, C.K. (1976): Fine structure of the testis and epididymis of rats treated with cyproteron acetate. Am. J. Anat. 146: 359- 365.

Fraiser, L.H.; Kanekal, S. and Kehrer, J.P. (1991): Cyclophosphamide toxicity characterizing and avoiding the problem. Drugs 42: 81-95. 
Friedman, H.S.; Pegg, A.E.; Johnson, S.P.; Loktionova, N.A.; Dolan, M.E.; Modrich, P. and Moschel, RC, et al., (1999): Modulation of cyclophosphamide activity by O6-alkylguanineDNAalkyltransferase. Cancer Chemother Pharmacol 43: 80-85.

Fukushima, T.; Yamamoto, T.; Kikkawa, R.; Hamada, Y.; Komiyama, M.; Mori, C. and Horii, I. (2005): Effects of male reproductive toxicants on gene expression in rat testes. J. Toxico Sci. 30: 195-206.

Galal, A.T.; Hassanein, A.M.M.; El-Sawi, N.M.; Mohammed, M.M. and $A l i$, S.S. (1994): Quantitative and qualitative studies on the seminiferous epithelium of albino rats under the effect of cytotoxic drugs. Assiut Vet. Med. J. 31: 1-18.

Hales, B.F.; Barton, T.S. and Robaire, B. (2005): Articles Impact of Paternal Exposure to Chemotherapy on Offspring in the Rat. J. Natl Cancer Inst Monogr 34: 28-31

Hales, B.F.; Crosman, K. and Robaire, B. (1992): Increased postimplantation loss and malformations among the F2 progeny of male rats chronically treated with cyclophosphamide Teratology 45: $671-8$.

Higuchi, H.; Nakaoka, M.; Katsuda, Y.; Kawamura, S.; Kato, T. and Matsuo, M. (1995): Collaborative assessment of optimal administration period and parameters to detect effects on male fertility in the rat: effects of cyclophosphamide on the male reproductive system. J. Toxicol Sci. 20: 239-249.

Hoorweg-Nijman, J.J.; Delemarre-vande-Wall, H.A.; DeWall, F.C. and Behrendt, H. (1992): Cyclophosphamide-induced disturbance of gonadotropin secretion manifesting testicular damage. Acta Endocrinol 126: 143-148.

Howell, S. and Shalet, S. (1998): Gonadal damage from chemotherapy and radiotherapy. Endocrinol Metab Clin North Am. 27: 92743.

Howell, S. and Shalet, S. (1998): Gonadal damage from chemotherapy and radiotherapy. Endocrinol. Metab. Clin. North Am 27: 927943.

Iammarrone, E.; Balet, R.; Lower, A.M.; Gillott, C. and Grudzinskas, J.G. (2003): Male infertility. Best Pract Res. Clin. Obstet Gynaecol 17: 211-29. 
Kangasniemi, M.; Huhtaniemi, I. and Meistrich, M.L. (1996): Failure of spermatogenesis to recover despite the presence of a spermatogonia in the irradiated LBNF1 rat. Biol Reprod 54: 1200-1208.

Katoh, C.; Kitajima, S.; Saga, Y.; Kanno, J.; Horii, I. and Inoue, T. (2002): Assessment of quantitative dual-parameter flow cytometric analysis for the evaluation of testicular toxicity using cyclophosphamide and ethinylestradiol treated rats. J. Toxicol Sci. 27: 87-96.

Kaur, F.; Sangha, G.K. and Bilaspuri, G.S. (1997): Cyclophosphamide induced structural and biochemical changes in testis and epididymidis of rats, Indian J. Exp. Biol 35: 771-775.

Kenney, L.B.; Laufer, M.R.; Grant, F.D.; Grier, H. and Diller, L. (2001): High risk of infertility and long term gonadal damage in males treated with high dose cyclophosphamide for sarcoma during childhood. Cancer 91:613-21.

Kumar, R.; Biggart, J.D.; McEvoy, J. and McGeown, M.G. (1972): Cyclophosphamide and reproductive function. Lancet 1: 1212-4.

Lu, C.C. and Meistrich, M.L. (1979): Cytotoxic effects of chemotherapeutic drugs on mouse testis cells. Cancer Res. 39: 3575- 3582.

Martinova, Y.; Topasshka-Ancheva, M.; Konstantinova, S.; Petkova, S.; Karaivanova, M. and Berger, M. (2006): Miltefosine decreases the cytotoxic effect of Epirubicine and cyclophosphamide on mouse spermatogenic, thymic and bone marrow cells. Arch Toxicol 8: 27-33.

Matsui, H.; Mistsumori, K.; Yasuhara, K.; Onodera, H.; Shimo, T. and Takahashi, M. (1995): Morphological evaluation of cyclophosphamide testicular toxicity in rats using quantitative morphometry of spermatogenic cycle stages. J. Toxicol Sci. 20: 407- 414.

Matsumoto, S.; Hirakawa, M.; Shimomoto, T.; Sato, M.; Kitaura, K. and Minami, T. (2000): Collaborative work to evaluate toxicity on male reproductive organs by repeated dose studies in rats. Effectsof a single oral dose of cyclophosphamide. J. Toxico Sci 25 special Issue: 139-143. 
McLachlan, R.I.; O’Donnell, L.; Meachem, S.J.; Stanton, P.G.; de Kretser, D.M.; Pratis, K. and Robertson, D.M. (2002): Identification of specific sites of hormonal regulation in spermatogenesis in rats, monkeys, and man. Recent Prog Horm Res. 57: 49-79.

Meistrich, M.L. (1998): Hormonal stimulation of the recovery of spermatogenesis following chemo or radiotheraphy: review article. Apmis 106: 37-45.

Meistrich, M.L.; Finch, M.; da Cunha, M.F.; Hacker, U. and Au. W.W. (1982): Damaging effects of fourteen chemotherapeutic drugs on mouse testis cells. Cancer Res. 42:122-31.

Meistrich, M.L. and Kangasniemi, M. (1997): Hormone treatment after irradiation stimulates recovery of rat spermatogenesis from surviving spermatogonia. J. Androl 18: 80-87.

Meistrich, M.L.; Parchuri, N.; Wilson, G.; Kurdoglu, B. and Kangasniemi, M. (1995): Hormonal protection from cyclophosphamide-induced inactivation of rat stem spermatogonia. J. Androl 16: 334-41.

Meistrich, M.L.; Wilson, G.; Brown, B.W.; da Cunha, M.F. and Lipshultz, L.I. (1992): Impact of cyclophosphamide on longterm reduction in sperm count in men treated with combination chemotherapy for Ewing and soft tissue sarcomas. Cancer 70: 2703-12.

Meistrich, M.L.; Wilson, G.; Kangasniemi, M. and Huhtaniemi, I. (2000): Mechanism of protection of rat spermatogenesis by hormonal pretreatment: stimulation of spermatogonial differentiation after irradiation. J. Androl 21: 464-9.

Meistrich, M.L. (1986): Relationship between spermatogonial stem cell survival and testis function after cytotoxic therapy. Brit $\mathrm{J}$. Cancer 53: 89-101.

Oh, M.S.; Chang, M.S.; Park, W.; Kima, D.R.; Baeb, H.; Huhc, Y. and Park, S.K. (2007): Yukmijihwang-tang protects against cyclophosphamide-induced reproductive toxicity. Reproductive Toxicology 24: 365-370.

Perini, P.; Calabrese, M.; Rinaldi, L. and Gallo, P. (2007): The safety profile of cyclophosphamide in multiple sclerosis therapy. Expert Opin Drug Saf 6: 183-190.

Peterson, R.G. (1985): Design and analysis of experiments. Marcel Dekker, Inc., New York. 
Preston, R.J.; Fennell, T.R.; Leber, P.; Sielken Jr, R.L. and Swenberg, J.A. (1995): Recommendation of the genetic risk assessment for ethylene oxide exposures. J. Environ Mol Mutagen 26: 189-202.

Rajinder, K.; Sangha, G.K. and Bilaspuri, G.S. (1997): Cyclophosphamide-induced structural and biochemical changes in testis and epididymis of rats. Indian J. Exper Biol. 35: 771-775.

Ridola, V.; Fawaza, O.; Aubier, F.; Bergerond, C.; Vathaire, F.; Pichonf, F. and Orbachg D, et al., (2009): Testicular function of survivors of childhood cancer: A comparative study between ifosfamide- and cyclophosphamide-based regimens. Eur J. Cancer in press.

Russell, L.D.; Ettlin, R.A.; SinhaHikim, A.P. and Clegg, E.D. (1990): Mammalian Spermatogenesis. In: Evaluation of the Testis. Cache River Press, Clearwater 1-40.

Russell, L.D. and Russell, J.A. (1991): Short-term morphological response of the rat testis to administration of five chemotherapeutic agents. Am. J. Anat chemotherapeutic agents. Am. J. Anat 192: $142-168$.

Sancar, A.; Lindsey-Boltz, L.A.; Unsal-Kacmaz, K. and Linn, S.( 2004): Molecular mechanisms of mammalian DNA repair and the DNAdamage checkpoints. Annu Rev. Biochem. 73: 39-85.

Satoh, K.; Ohyama, K.; Nakagomi, Y.; Ohta, M.; Shimura, Y.; Sano, T.; Ishikawa, H.; Amemiya, S. and Nakazawa, S. (2002): Effects of growth hormone on testicular dysfunction induced by cyclophosphamide (CP) in GH-Deficient rats. Endocrine J. 49: 611-619.

Schimenti, K.J.; Hanneman, W.H. and Schimenti, J.C. (1997): Evidence for cyclophosphamide- induced gene conversion and mutation in mouse germ cells. Toxicol. Appl. Pharmacol. 147: 343-350.

Schrader, M.; Heicappel, R.; Muller, M.; Straub, B. and Miller, K. (2001): Impact of chemotherapy on male fertility. Onkologie 24: 326-30.

Selvakumar, E.; Prahalathan, C.; Sudharsan, P.T. and Varalakshmi, P. (2006a): Protective effect of lipoic acid on cyclophosphamideinduced testicular toxicity. Clin. Chim Acta 367: 114-119 
Selvakumar, E.; Prahalathan, C.; Sudharsan, P.T. and Varalakshmi, P. (2006b): Chemoprotective effect of lipoic acid against cyclophosphamide-induced changes in the rat sperm. Toxicology 217: 71-78.

Shafford, E.A.; Kingston, J.E.; Malpas, J.S.; Plowman, P.N.; Pritchard, J. and Savage, M.O., et al. (1993): Testicular function following the treatment of Hodgkin's disease in childhood. Br. J. Cancer 68:1199-204.

Shalet, S.M.; Hann, I.M.; Lendon, M.; Morris Jones, P.H. and Beardwell, C.G. (1981): Testicular function after combination chemotherapy in childhood for acute lymphoblastic leukemia. Arch Dis. Child 56: 275-8.

Sotomayor, R.E. and Cumming, R.B. (1975): Induction of translocations by cyclophosphamide in different germ-cell stages of male micecytological characterization and transmission. Mutat Res 27: 375-388.

Suter, L.; Koch, E.; Bechter, R. and Bobadilla, M. (1997): ThreeParameter Flow Cytometric Analysis of Rat spermatogenesis Cytometry 27:161-168.

Takahashi, M. and Matsui, H. (1993): Mechanisms of testicular toxicity. J. Toxicol. Pathol., 6, $161-174$.

Tates, A.D. (1992): Validation studies with the micronucleus test for early spermatids of rats. A tool for detecting clastogenicity of chemicals in differentiating spermatogonia and spermatocytes. Mutagenesis 7: 411-419.

Trasler, J.M.; Hales, B.F. and Robaire, B. (1986): Chronic low dose cyclophosphamide treatment of adult male rats: effect on fertility, pregnancy outcome and progeny Biol. Reprod. 34: 275-83.

Tripathi, D.N. and Jena, G.B. (2008): Astaxanthin inhibits cytotoxic and genotoxic effects of cyclophosphamide in mice germ cells. Toxicol. 248: 96-103

Uber, W.E.; Self, S.E.; Van Bakel, A.B. and Pereira, N.L. (2007): Acute antibody-mediated rejection following heart transplantation. Am. J. Transplant 7: 2064-2074.

Uderzo, C.; Locasciulli, A.; Msarzorati, R., Adamoli, L.; Di-Natala, B.; Nizzoli, G.; Gazzaniga, M. and Masera, G. (1984): Correlation of gonadal function with histology of testicular biopsies at treatment discontinuation in childhood acute leukemia. Med. Pediatr Oncol 12: 97-100. 
Velez de la Calle, J.F.; de Queiroz, F.; Garnier, D.H.; Kercret, H.; Folliot, R. and Jegou, B. (1989): Reproductive effects of the anticancer drug.

Wang, X.; Zhang, J. and Xu, T. (2007): Cyclophosphamide as a potent inhibitor of tumor thioredoxin reductase in vivo. Toxicol. and Applied Pharmacol. 218: 88-95.

Watanabe, T.; Norikazu, Y.; Tomohide, A.; Masahir, T. and Masayoshi, T. (2000): Collaborative work to evaluate toxicity on male reproductive organs by repeated dose studies in rats. Effects of cyclophosphamide on spermatogenesis. J. Toxic Sci. 25: 129137.

Ye, S.J.; Ying, L.; Gosh, S.; Renato, L. and Russell, L.D. (1993): Sertoli cell cycle: a re-examination of the structural changes during the cycle of the seminiferous epithelium of the rat. The Anat. Rec. 237: $187-198$. 